ISSN (print): 1698-6180. ISSN (online): 1886-7995

www.ucm.es/info/estratig/journal.htm

Journal of Iberian Geology 38 (1) 2012: 191-208

http://dx.doi.org/10.5209/rev_JIGE.2012.v38.n1.39213

\title{
Recent and active faults and folds in the central-eastern Internal Zones of the Betic Cordillera
}

\author{
Las fallas y pliegues recientes y activos de la parte centro-oriental de las \\ Zonas Internas de la Cordillera Bética
}

\author{
A. Pedrera*1, J. Galindo-Zaldívar ${ }^{2,3}$, C. Marín-Lechado ${ }^{1}$, F.J. García-Tortosa ${ }^{4}$, P. Ruano ${ }^{2,3}$, \\ A.C. López Garrido ${ }^{3}$, J.M. Azañón ${ }^{2,3}$, J.A. Peláez ${ }^{5}$, and F. Giaconia ${ }^{2}$ \\ ${ }^{1}$ Instituto Geológico y Minero de España-Ríos Rosas 23, 28003 Madrid, Spain. \\ 2 Departamento de Geodinámica, Universidad de Granada 18071-Granada, Spain. \\ ${ }^{3}$ Instituto and Andaluz de Ciencias de la Tierra, CSIC- Universidad de Granada, 18071-Granada, Spain. \\ ${ }^{4}$ Dpto. de Geología, Universidad de Jaén, Campus Las Lagunillas 23071 Jaén, Spain. \\ ${ }^{5}$ Dpto de Física, Universidad de Jaén, Campus Las Lagunillas 23071 Jaén, Spain.
}

*Corresponding author: a.pedrera@igme.es

Received: 05/07/2011 / Accepted: 25/01/2012

\begin{abstract}
The most recent tectonic structures of the central-eastern Internal Zones of the Betic Cordillera (from $3.1^{\circ} \mathrm{W}$ to $1.7^{\circ} \mathrm{W}$ and to the south of $37.525^{\circ} \mathrm{N}$ ) include fault and folds developed from the Late Miocene onwards, which are related to N-S/NW-SE directed continental collision and moderate thickening of a crust that is relatively hot at depth. In this setting, E-W to WSW-ENE folds, with locally associated E-W transpressive right-lateral and reverse faults, favoured the emersion of the northern Alborán basin palaeomargin and the progressive intramontane basin disconnection. The NNE-SSW to NE-SW trending regional left-lateral Palomares and Carboneras fault zones are dominant structures in the easternmost part of the cordillera. In addition, NW-SE to WNWESE trending normal and oblique-slip normal faults are widespread. The collision is still active and continues to drive active folds and faults, some probably being the likely source of moderate-sized earthquakes. The Campo de Dalías and surrounding sectors, deformed by active ENE-WSW folds and NW-SE to WNW-ESE oblique-slip normal faults, are probably the sites with the largest concentration of significant earthquakes during recent years. Moderate-magnitude earthquakes (Mw 5.0 to 6.5) have occurred there at fairly regular intervals, in 1804, 1910, and 1994. Toward the east, NW-SE trending normal faults extending from Almería to the Tabernas basin deform the Quaternary rocks with associated moderate seismicity (the 2002 Gergal Mw 4.7 earthquake, and possibly the 1894 Nacimiento earthquake, felt with intensity VII). In the Sorbas-Vera basin, the Palomares fault zone is also responsible for moderate-sized earthquakes (1518 Vera earthquake). In the Almanzora corridor, NW-SE to WNW-ESE trending Lúcar-Somontín faults also could be considered one of the possible source of moderate-magnitude seismicity (1932 Lúcar, Mw 4.8 earthquake felt
\end{abstract}


with intensity VIII). Toward the east, between Albox and Partaloa, several small reverse faults and associated compressive structures deform Quaternary alluvial and fluvial sediments. Although some of these folds reveal a slow and progressive deformation from the Middle Pleistocene onwards, some of these reverse fault segments that deform the western Huércal-Overa basin could host the 1972 NW Partaloa, mbLg 4.8 earthquake, felt with intensity VII.

Keywords: Active Tectonics; Earthquakes; Tectonic Evolution; Gibraltar Arc.

\section{Resumen}

Las estructuras tectónicas más recientes que deforman la parte centro-oriental de las Zonas Internas de Cordillera Bética (entre $3.1^{\circ}$ y $1.7^{\circ} \mathrm{O}$ y al sur de $37.525^{\circ} \mathrm{N}$ ) son fallas y pliegues que comenzaron a formarse aproximadamente en el Mioceno superior en un contexto de colisión continental N-S/NO-SE y moderado engrosamiento cortical. En este marco tectónico, pliegues y fallas transpresivas dextras e inversas de direcciones E-O/OSO-ENE favorecieron la emersión del borde norte de la paleocuenca de Alborán y la progresiva desconexión de pequeñas cuencas intramontañosas. Además, comenzaron a formarse las grandes zonas de falla de Palomares y Carboneras, con direcciones NNE-SSO y NE-SO respectivamente y movimientos sinistros, que también han condicionado la evolución de la Cordillera Bética oriental desde el Mioceno superior. Algunas fallas con salto normal/normal-oblicuo y trazas NO-SE/ONO-ESE también se han desarrollado ampliamente en toda la zona de estudio. La colisión, aún activa, permite que algunos pliegues y fallas continúen propagándose en la actualidad, eventualmente causando terremotos con magnitudes moderadas. El Campo de Dalías y los sectores adyacentes, deformados por pliegues activos de direcciones ENE-OSO y fallas NO-SE/ONOESE normales-oblicuas, probablemente representan la zona con mayor concentración de terremotos importantes (Mw 5.0-6.5) con eventos recurrentes en 1804, 1910 y 1994. Al este del Campo de Dalías, una amplia zona de falla normal se extiende en dirección NO-SE desde Almería hasta la cuenca de Tabernas. Esta zona de falla muestra evidencias de funcionamiento durante el Cuaternario y tiene sismicidad moderada asociada a su terminación septentrional (el terremoto de Gergal en 2002 con Mw 4.7; y posiblemente el terremoto de Nacimiento en 1894 con intensidad VII). La zona de falla de Palomares es también responsable de terremotos moderados en la Cuenca de Sorbas-Vera (terremoto de Vera en 1518). En la parte central del corredor del Almanzora, alguno de los segmentos de falla normal que se extienden entre Lúcar y Somontín podría ser responsable del terremoto de Lúcar, en 1932 (Mw 4.8 e intensidad VIII). Al este, entre Albox y Partaloa, se han descrito fallas inversas y pliegues asociados que deforman sedimentos cuaternarios. Aunque algunas de estas estructuras muestran evidencias de funcionamiento lento y progresivo durante el Cuaternario, el terremoto de Partaloa en 1972 (mbLg 4.8 e intensidad VII) pudo ser causado por la actividad de cualquiera de estos segmentos de falla inversa que deforman la parte occidental de la cuenca de Huércal-Overa.

Palabras clave: Sismicidad, Tectónica Activa; Terremotos; Evolución Tectónica; Arco de Gibraltar.

\section{Introduction}

The recent and active tectonic structures of the Betic Cordillera have attracted attention of Earth scientists since the 1970s (Andrieux et al., 1971; Biju Duval et al., 1977; Groupe de Recherche Neotectonique, 1977; Bousquet and Montenat, 1974; Bousquet and Phillip, 1976; Bousquet, 1979), and since then, much geological and geomorphological research has been focused on their identification in order to establish the mechanisms responsible for the tectonic evolution of the orogen (e.g., Sanz de Galdeano, 1983; Ott d'Estevou and Montenat, 1985; Sanz de Galdeano, 1990) and to estimate their seismogenic potential (e.g., Sanz de Galdeano and López Casado, 1988; Sanz de Galdeano et al., 1995). While the location, geometry, and kinematics of the main structures are well established, the processes involved in their development and the present-day activity of some of these structures are still under debate. It is widely accepted that compressional and extensional structures have deformed the Internal Zones of the Betic Cordillera since the Late Miocene. This region exhibits a variety of deformational styles, dominated by folds, right-lateral and normal faults in the central Betics (e.g., Galindo-Zaldívar et al., 2003), and by large left-lateral strike-slip faults in the eastern sector of the cordillera that also interact with folds and normal/normal-oblique faults (e.g., Martínez-Díaz, 2002; Masana et al., 2004; Booth-Rea et al., 2003; Pedrera et al., 2010a). The present study attempts to sketch a coherent picture of these recent tectonic structures that deform the central-eastern (from the longitude $3.1^{\circ} \mathrm{W}$ to $1.7^{\circ} \mathrm{W}$ and to the south of $37.525^{\circ} \mathrm{N}$ ) Internal Zones of the Betic Cordillera (Fig. 1). Special attention is placed on the faults and folds that have been active during Quaternary times, which are potential sources of future earthquakes.

\section{Geological setting}

The Betic Cordillera, together with the Rif, constitutes the westernmost part of the Alpine Mediterranean belt in the convergent Eurasian and African plate boundary (Fig. 1A). The Alpine evolution of the orogen is determined by the interaction between the two major plates and the intermediate placed Alborán Domain (Internal 

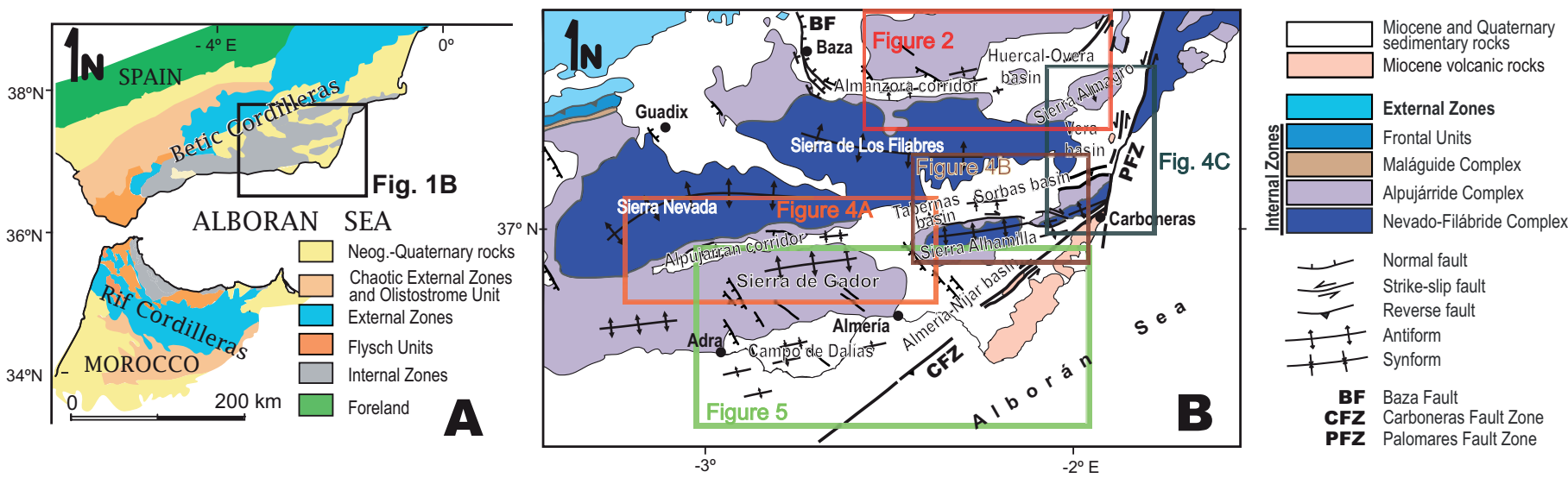

Fig. 1.- (A) Simplified geological map of the Betic and Rif Cordilleras including the location of figure 1B. (B) Geological sketch map of the central-eastern Betic Cordillera with the positions of the neotectonic maps of figures 2, 4A, 4B, 4C, 5 .

Fig. 1.- (A) Mapa geológico simplificado de las Cordilleras Bético-Rifeñas con la posición de la figura 1B. (B) Mapa geológico simplificado del sector central y oriental de la Cordillera Bética con la localización de los mapas neotectónicos de la figuras 2, 4A, 4B, 4C, 5.

Zones of the Betic and Rif Cordillera) (e.g., Andrieux et al., 1971; Sanz de Galdeano, 1990). In a framework of continuous N-S to NW-SE convergence, subduction and subsequent collision, with the destruction of Mesozoic oceanic basins (e.g., Martín-Algarra, 1987) and slab rollback, reasonably explain the latest Oligocene to middle Miocene evolution of the Betic-Rif cordilleras and the development of the large Alborán basin (e.g., Lonergan and White, 1997). Therefore, during the early and middle Miocene the metamorphic rocks of the Alborán Domain were exhumed at the footwall of extensional brittle-ductile detachments (Aldaya et al., 1984; Galindo-Zaldívar, 1986; García-Dueñas and Martínez-Martínez, 1988; Jabaloy et al., 1993) and the Alborán basin was formed, floored by thinned continental crust, exhibiting a large arched sedimentary depocenter: theWest Alborán basin (Comas et al., 1992, 1999; Soto et al., 1996; Chalouan and Michard, 2004). Roughly since the late Miocene, the subduction shifted to N-S/NW-SE continental collision, the crust started to thicken, and the northern margin of the Alborán basin progressively emerged. Consequently, intramontane sedimentary basins gradually became isolated from the original Alborán basin, some completely emerging (e.g., Braga et al., 2003). This continent collision is still active at a rate of $4-5 \mathrm{~mm} / \mathrm{yr}$ (Argus et al., 1989; DeMets et al., 1990, 1994) and continues driving the development of active folds and faults (e.g., Sanz de Galdeano et al., 1995; Galindo-Zaldívar et al., 2003). Therefore, current displacement of the Earth's surface reveals the oblique convergence between the Iberian and African plates, showing a movement of the Eurasian plate and the Betic Cordillera toward the SSW/SW with respect to the African plate (Stich et al., 2006; Fadil et al.,
2006; Tahayt et al., 2008; Vernant et al., 2010), which is roughly in accordance with the present-day stress setting (e.g., Fernández-Ibáñez et al., 2007; Pedrera et al., 2011).

In the Betic Cordillera, the structures that formed since the late Miocene up to now have been classically designated as recent or neotectonic. These structures determine the spatial distribution of the uplifted areas subjected to erosion and the sedimentary basins. Below, we describe the recent and active structures that, from north to south, deform the Almanzora corridor and the HuércalOvera basin, the Alpujarran corridor and the Tabernas, Sorbas, and Vera basins, and the Campo de Dalías and the Almería-Níjar basin (Fig. 1B).

\section{The Almanzora corridor and the Huércal-Overa basin}

The Almanzora corridor and the Huércal-Overa basin are located between the Sierra de Los Filabres and Sierra de Las Estancias (Figs 1 and 2). Both basins are essentially filled by Serravallian-lower Tortonian continental/ fluvial-deltaic sediments, and became a marine realm during the late Tortonian. The marine-continental transition started in Messinian times. Continental sedimentation along rivers and alluvial fans together with erosion occurred during the Pliocene and Quaternary.

\subsection{Late Miocene tectonic structures}

Compressive and extensional structures deformed the late Miocene-Quaternary sediments of the Almanzora corridor and the Huércal-Overa basin (Briend, 1981; Briend et al., 1990; Mora-Gluckstadt, 1993; Poisson et al., 1999; 


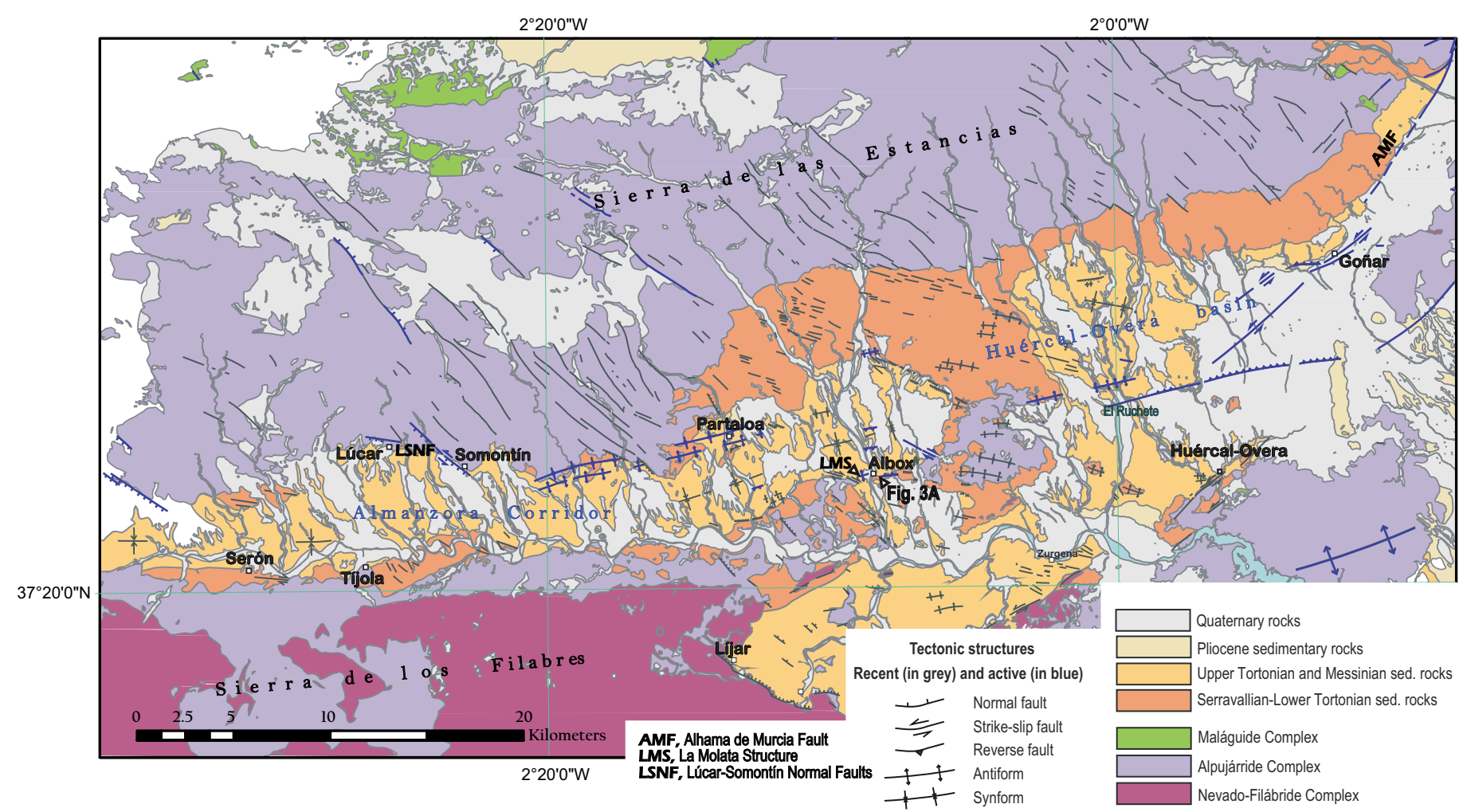

Fig. 2.- Geological map of the Almanzora corridor and the Huércal-Overa basin with traces of the recent (in grey) and active (blue) tectonic structures. The location of figure $3 \mathrm{~A}$ is marked.

Fig. 2.- Mapa geológico del Corredor del Almanzora y la Cuenca de Huércal-Overa que incluye las trazas de las estructuras tectónicas recientes (en gris) y activas (en azul). La posición de la figura 3A está indicada.

Augier, 2004; Augier et al., 2005; Meijninger and Vissers, 2006; Pedrera et al., 2007; Pedrera et al., 2010a). The study area was deformed by a succession of kilometric scale folds with orientations ranging from E-W to ENE-WSW: the Sierra de Los Filabres and Sierra de Almagro antiforms, Almanzora corridor synform and Sierra de Las Estancias antiform (Booth-Rea et al., 2003, 2004; Pedrera et al., 2007, 2009b). The antiforms coincide with the ranges where the metamorphic rocks crop out, while the synforms correspond to the sedimentary basins. Folding started there with the Sierra de los Filabres antiform nucleation during Serravallian-early Tortonian, as revealed by the syntectonic angular unconformities founded in its northern limb (Pedrera et al., 2007). Large-scale folds continued growing and propagating to the north, forming the Almanzora corridor in the late Tortonian (Pedrera et al., 2007). Moreover, the sedimentary rocks have been deformed since late Tortonian by ENE-WSW minor folds (Pedrera et al., 2007; Pedrera et al., 2010a). To the east, these minor folds progressively change their trend from ENE-WSW to WNW-ESE (Pedrera et al., 2010a). In addition, the late Miocene sediments are quite deformed by several sets of faults. The most abundant set is formed by WNW-ESE to NW-SE normal faults that show a wi- despread distribution in the basins (Briend, 1981; Briend et al., 1990; Mora-Gluckstadt, 1993; Poisson et al., 1999; Augier, 2004; Augier et al., 2005; Meijninger and Vissers, 2006; Pedrera et al., 2007; Pedrera et al., 2010a). Subvertical strike-slip dextral faults, E-W to ESE-WNW oriented, deformed the Tortonian sediments that crop out mainly in the southern Almanzora corridor boundary (Fig. 2; Poisson et al., 1999; Pedrera et al., 2007).

\subsection{Active tectonic structures}

The westernmost part of the Almanzora corridor is affected by a set of NW-SE faults that deform up to the Quaternary glacis and constitute the western end of the corridor. These fault segments are related to the normal Baza fault (Alfaro et al., 2008; García-Tortosa et al., 2008; Sanz de Galdeano et al., this volume), which extends more than $30 \mathrm{~km}$ along the Baza basin, showing a $\mathrm{N}-\mathrm{S}$ to NW-SE variable strike, and dipping to the NE (Fig. 1B). In the central part of the corridor, the Lúcar fault formed by a set of ENE-WSW oriented and $40^{\circ}-75^{\circ}$ south dipping normal faults - locally deforms the Quaternary sediments. Close to Somontín, the Quaternary sediments are deformed by a NW-SE oriented high-dipping fault 
that generates a steep scarp. The fault surface shows horizontal striation with a left-lateral sense of motion overprinted on the normal striation. The eastern Almanzora corridor (Somontín-Partaloa sector) and the western Huércal-Overa basin are both deformed by widespread small-scale contractional tectonic structures, which include WNW-ESE trending dextral faults and ENE-WSW oriented open folds, fault-propagation folds, and reverse faults (Figs. 2 and 3A; Briend et al., 1990; Pedrera et al., 2009a and 2009b). Using a geomorphological approach, García-Meléndez (2000) and García-Meléndez et al. (2004) defined the Albox fault as an ENE-WSW to E-W fault zone with reverse-dextral kinematics that runs from the eastern Huércal-Overa basin as far as the Almanzora corridor to the west. The La Molata fault-propagation fold is one of the best-exposed outcrops (Fig. 2, Pedrera et al., 2009a. This fold and its related faults have propagated progressively, as evidenced by the syn-tectonic geometry of the growth strata. Strain rates calculated across the structure give a constant $\sim 0.007 \mathrm{~mm} / \mathrm{yr}$ horizontal shortening and $\sim 0.014 \mathrm{~mm} / \mathrm{yr}$ vertical displacement from the mid-Pleistocene to the present (Pedrera et al., 2009a). The central and eastern part of the Huércal-Overa basin is deformed by ENE-WSW trending reverse faults with a splay geometry, belonging to the southern end of the Alhama de Murcia left-lateral transcurrent fault (AMF) (Martínez-Díaz et al., this volume). These faults deform the Quaternary alluvial fan deposits in the eastern Huércal-Overa basin (Groupe de Recherche Néotectonique, 1977; Briend, 1981) and have been recently characterized with geomorphological, structural, and paleoseismologic studies (García-Meléndez et al., 2003; Soler et al., 2003; Masana et al., 2005; Meijninger and Vissers, 2006; Ortuño et al., 2009). Thus, paleoseismologic studies near Goñar (Fig. 2) in the eastern Huércal-Overa basin, identify at least two paleoearthquakes associated with the AMF during the last $150 \mathrm{ka}$ and estimate a minimum vertical slip rate of $\sim 0.02 \mathrm{~mm} / \mathrm{yr}$ in the southern fault termination since the Middle Pleistocene (Ortuño et al., 2009). In addition, a palaeoseismologic study in El Ruchete sector (Fig. 2) identified fault segments with short-term sliprates ranging from 0.01 to $0.4 \mathrm{~mm} / \mathrm{yr}$ and two possible paleoearthquakes deposits associated with them (Masana et al., 2005). This reverse fault segment probably belongs to the horsetail reverse splay of the AMF (Fig. 2).

The drainage network of the Almanzora River, highly controlled by the above structures, reflects the activity of the faults and folds since the Messinian (Stokes, 2008; Stokes and Mather, 2000, 2003; Pedrera et al., 2009c). The presence of normal faults condition small changes in the direction of the north Almanzora River tributary stream. In addition, the role of the above-described active folds in the landscape evolution and drainage development was characterized in the folded eastern Almanzora corridor and western Huércal-Overa basin (Pedrera et al., 2009c).

\section{The Alpujarran corridor, the Tabernas basin, and the Sorbas-Vera basin}

The Alpujarran corridor is an E-W elongated valley formed by a roughly synformal structure located between the Sierra Nevada to the north and the Sierras LújarContraviesa-Gádor to the south. Eastwards the corridor extends to the Tabernas basin, which continues into the Sorbas-Vera basin, between Sierra de Los Filabres to the north and Sierra Alhamilla and Sierra Cabrera to the south (Figs. 1 and 4). These basins are partially filled with lower Miocene to Quaternary deposits and constitute a zone of crustal weakness where recent and active deformation structures are nucleated (Ott d'Estevou et al., 1990; Rodríguez-Fernández, 1982). Researchers agree on the presence throughout this area of a main right-lateral fault zone (e.g., Sanz de Galdeano et al., 1985; Galindo-Zaldívar, 1986; Sanz de Galdeano, 1989; Jabaloy et al., 1992; Galindo-Zaldívar et al., 2003; Martínez-Díaz and Hernández-Enrile, 2004; Martínez-Martínez, 2006; Martínez-Martínez et al., 2006; Sanz de Galdeano et al., 2010). However, controversy persists concerning the deep continuity of the structures, the relationships of the exposes faults with seismicity, the driving mechanisms, and in some cases the age of fault activity. On the other hand, there is a general consensus regarding the features of the major left-lateral Palomares fault zone (PFZ), which developed since the late Tortonian in the eastern part of the Sorbas-Vera basin (e.g., Bousquet and Phillip, 1976; Bousquet, 1979; Montenat et al., 1987; Weijermars, 1987; Ott d'Estevou et al., 1990; Silva et al., 1993; Booth-Rea et al., 2003).

\subsection{Miocene tectonic structures}

After the end of metamorphism in the Internal Zones, a set of top-to-the west low-angle normal faults thinned the crust and exhumed the Nevado-Filábride complex, up to the middle Miocene (e.g., Aldaya et al., 1984; Galindo Zaldívar, 1986; García-Dueñas and MartínezMartínez, 1988; Jabaloy et al., 1993). Afterwards, the crustal-thinning process shifted to crustal thickening and relief formation, when the Sierra Nevada and Sierra de los Filabres started to emerge (Braga et al., 2003) as large antiforms that folded the extensional detachments 

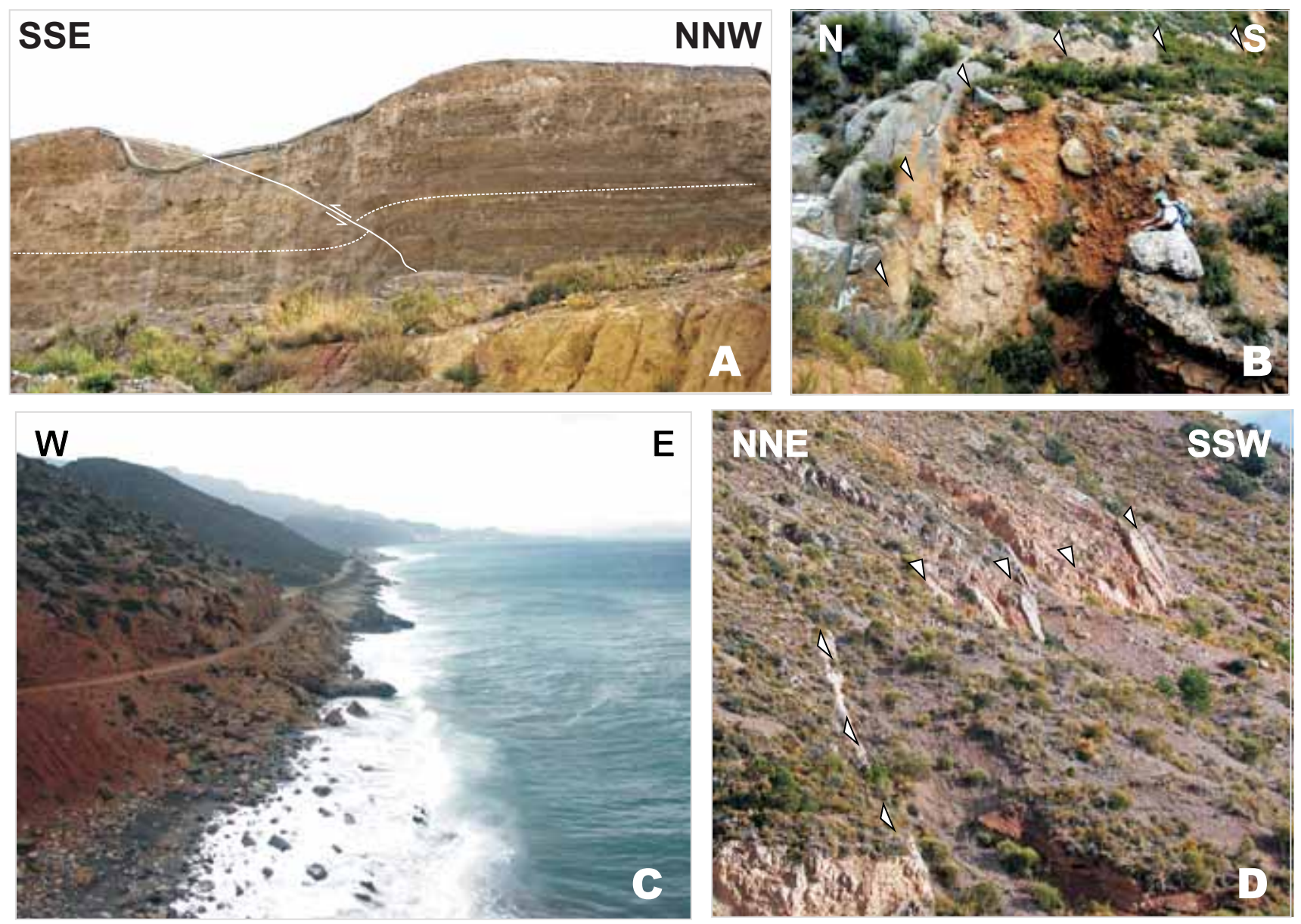

Fig. 3.- Field view of several active tectonic structures placed in the central-eastern Betic Cordillera. (A) ENE-WSW trending reverse fault and associated antiform that deform Quaternary conglomerates near Albox in the Huércal-Overa basin. (B) Laujar de Andarax normal fault: E-W oriented normal fault dipping toward the south affecting Quaternary sedimentary rocksin the northern Alpujarran corridor margin. (C) Rectilinear coast line that coincides with a fault segment of the left-lateral Palomares fault zone, which controls the eastern termination of the Sierra Cabrera. (D) Balanegra fault zone: NW-SE oriented normal fault segment that deforms Quaternary sediments in the western termination of the Sierra de Gádor, close to the village of Berja.

Fig. 3.- Ejemplos de algunas estructuras activas situadas en el área de estudio. (A) Falla inversa y pliegue asociado de direcciones ENEOSO que deforman conglomerados cuaternarios en las proximidades de Albox, en la Cuenca de Huércal-Overa. (B) Falla normal de Laujar de Andarax: segmento que afecta a sedimentos cuaternarios con dirección aproximada E-O y buzamiento hacia el Sur. (C) Tramo de costa rectilíneo asociado a un segmento de la Falla de Palomares que controla la terminación oriental de Sierra Cabrera. (D) Zona de falla de Balanegra: segmento de dirección NO-SE que deforma sedimentos cuaternarios en la terminación occidental de la Sierra de Gador, cerca de Berja.

(Martínez-Martínez et al., 1995; Martínez-Martínez and Azañón, 1997; Galindo-Zaldívar et al., 2003; Pedrera et al., 2009b). The deformation also propagated southward since the late Tortonian with the development of E-W kilometre-sized folds (Weijermars, 1985) that determined the isolation of the Alpujarra-Tabernas-Sorbas corridor (Fig. 4). A major E-W right-lateral fault zone composed by subvertical fault segments runs within the corridor (Sanz de Galdeano et al., 1985), developing foliated cataclasites and fault-bound lenses (Sanz de Galdeano et al., 1985). Faults segments with intermediate to low dips and oblique-slip including normal and reverse components have been also described, as in the Ugijar area (Fig. 4A; Galindo-Zaldívar, 1986).
Eastwards, E-W strike-slip faults segments are also well developed running along the southern part of the western Tabernas basin (Sanz de Galdeano et al., 2010) and the northern boundary of Sierra Alhamilla antiform, the so-called Lucainena fault (Sanz de Galdeano, 1989) (Fig. 4A, B). The Lucainena fault branches into two segments to the east (Sanz de Galdeano, 1989). The northern segment, which runs near Gafarillos village, changes it orientation from E-W to NW-SE and cross-cut upper Tortonian sediments and the metamorphic rocks of the Sierra Cabrera (Sanz de Galdeano, 1989). This fault segment is usually called the Gafarillos fault (Stapel, 1996; Huibregtse et al., 1998; Jonk and Bierman, 2002) or North Gafarillos fault (Giaconia et al., 2012). The southern 
fault segment runs from Los Guardianes, near Polopos village, to the southern boundary of Sierra Cabrera antiform with an ENE-WSW trend, being called the Polopos fault (Keller et al., 1995) or the South Gafarillos fault (Fig. 4; Giaconia et al., 2012).

The E-W right-lateral faults along the Alpujarras, the E-W oriented right-lateral faults of the southern Tabernas basin, and the dextral-reverse faults in the southern Sorbas basin have been traditionally interpreted as transpressive faults developed under N/S to NNW/SSE compression (e.g., Sanz de Galdeano et al., 1985, 1989; Stapel, 1996; Huibregtse et al., 1998; Jonk and Bierman, 2002). However, Martínez-Martínez (2006) and Martínez-Martínez et al. (2006) propose a different interpretation for the Alpujarra right-lateral faults. They consider this fault zone to be part of a WSW-directed extensional system connecting two normal fault systems that thinned the Betic hinterland since the middle Miocene to the present.
In the absence of accurate, deep geophysical data, the deep continuity of the right-lateral faults has been considered to have a crustal (Sanz de Galdeano et al., 1985) or at least shallow crustal character (Martínez-Díaz and Hernández-Enrile, 2004; Martínez-Martínez et al., 2006), although Galindo-Zaldívar (1986) suggests that fault structures of the central Alpujarras corridor are restricted to the shallowest part of the crust.

Toward the east, the Palomares fault zone (PFZ), which is formed by several $\mathrm{N} 10^{\circ} \mathrm{E}$ to $\mathrm{N} 20^{\circ} \mathrm{E}$ left-lateral fault segments, deforms the eastern sector of the Vera basin (Fig. 4C) (Bousquet and Phillip, 1976; Bousquet, 1979; Weijermars, 1987). The Miocene sediments of the Vera basin are involved within the fault zone. Therefore, two depocenters filled by latest Tortonian to Quaternary sediments are linked to the movement of Arteal and Palomares fault segments (Fig. 4C; Booth-Rea et al., 2003). Thus, the PFZ is considered a transcurrent deformation zone
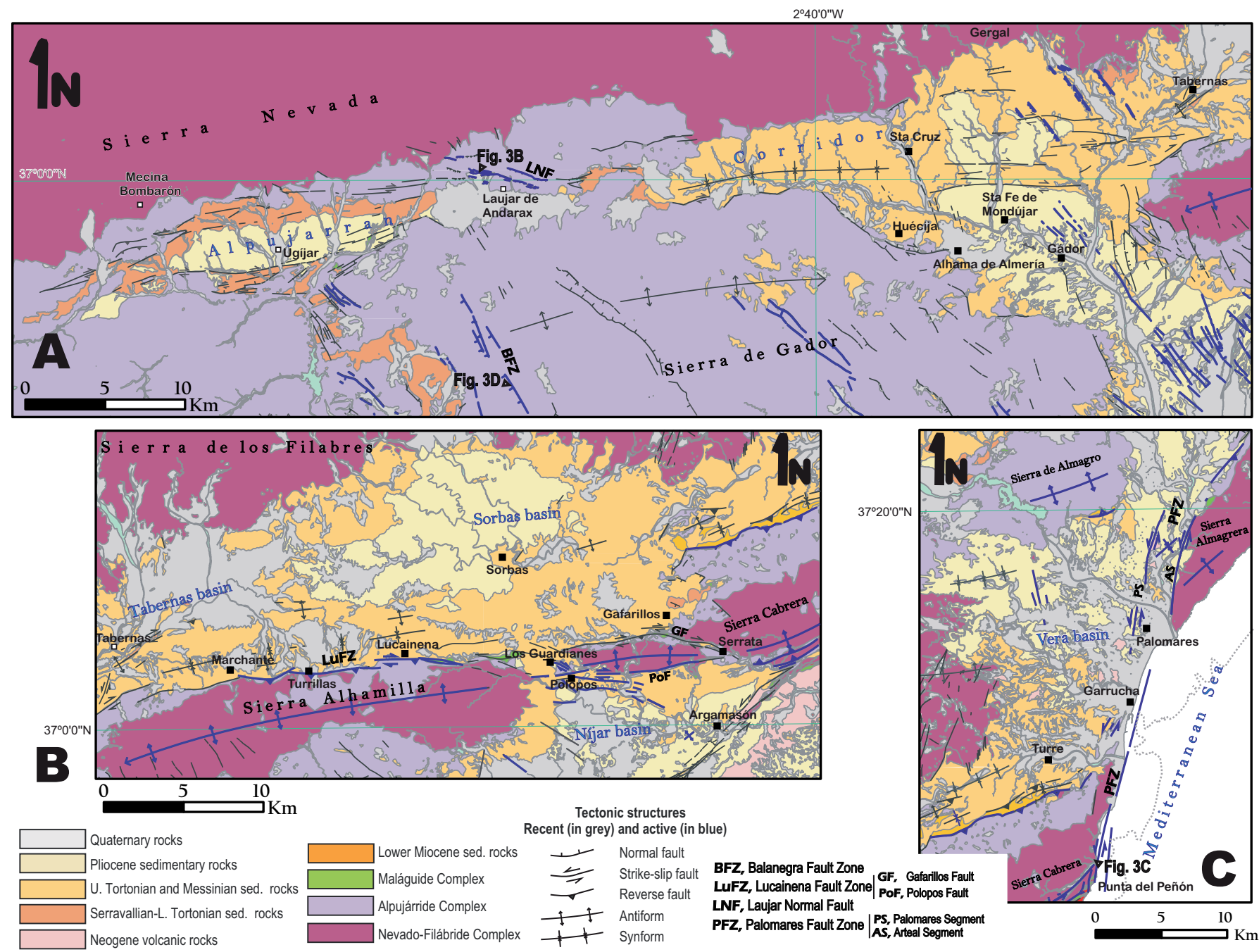

Fig. 4.- (A) Geological map of the Alpujarran corridor, (B) Tabernas/Sorbas basin, and (C) Vera basin showing traces of the recent (in grey) and active (blue) tectonic structures. The locations of figures $3 \mathrm{~B}$ and $\mathrm{C}$ are marked.

Fig. 4.- Mapa geológico del Corredor de las Alpujarras, (B) la Cuenca de Tabernas/Sorbas y (C) la Cuenca de Vera con las trazas de las estructuras tectónicas recientes (en gris) y activas (en azul). La posición de la figuras 3B y C están indicadas. 
active during most of the Neogene and Quaternary (e.g., Montenat et al., 1987; Ott d'Estevou et al. 1990; Silva et al., 1993; Ruano et al., 2007). Both ends are characterized by a change in the fault segments direction, which acquire a splay geometry that may be consistent with the development of reverse faults and antiforms since upper Miocene (Sierra Cabrera and Sierra Almagrera).

\subsection{Active tectonic structures}

The major dextral fault zone of the Alpujarra-TabernasSorbas basins may have continued its activity up to the Quaternary (Sanz de Galdeano et al., 1985; MartínezDíaz and Hernández-Enrile, 2004; Martínez-Martínez et al., 2006). Moreover, most of the dextral faults appear to be covered by the thin Plio-Quaternary sediments in the western Ugijar basin (Galindo-Zaldívar, 1986). Eastwards, the southern border of the Sorbas basin shows evidence of recent dextral oblique-reverse faulting (Sanz de Galdeano, 1989; Martínez-Díaz and Hernández-Enrile, 2004; Giaconia et al., 2012).

A clear evidence of Quaternary faulting is found in the eastern Alpujarran corridor, in the Laujar de Andarax zone (García-Tortosa and Sanz de Galdeano, 2007). This consists of an E-W trending fault zone formed by southward-dipping normal faults segments affecting Quaternary deposits (Fig. 3B and 4A). Quaternary faults with related seismic activity are also found along a NWSE zone that stretches from Almería to the Tabernas basin and separates Sierra Alhamilla from Sierra de Gádor (Sanz de Galdeano et al., 2010). Seismicity is concentrated in the basement at the north-western edge, near Gergal, and this may correspond to the area of propagation of the fault zone.

The dextral-reverse Polopos fault deforms the Messinian and locally Quaternary sedimentary rocks of the Níjar basin with (Sanz de Galdeano, 1989). A recent geomorphic analysis confirms that active tectonics influences the streams and hillslopes of the Sierra Alhamilla antiform related to the Polopos fault and identify Quaternary contractional deformation associated to the Lucainena fault zone to the east of Marchante (the North Alhamilla Reverse Fault of Giaconia et al., 2012).

The PFZ deforms Pleistocene conglomerates, close to Palomares village, developing an impressive fault-mirror with subhorizontal striations (Bousquet and Phillip, 1976). Pliocene-Quaternary sedimentary depocenters reveal that deformation along the PFZ fault zone migrated towards the eastern Arteal fault segment, which bounds the western mountain front of Sierra Almagrera (BoothRea et al., 2003). In addition, the Quaternary activity of the PFZ favoured stream dissection, headward erosion of streams transverse to the active fault segments, and the asymmetry of the drainage network (Booth-Rea et al., 2004; Stokes, 2008). The almost straight coastline from Palomares to Punta del Peñon is controlled by the PFZ (Figs. 3C and 4C), therefore the Late Pleistocene-Holocene marine terraces are uplifted along the coast (Goy and Zazo, 1986). In addition, Pleistocene conglomerates located in the Punta del Peñón contain numerous pebbles striated under the left-lateral shear of the PFZ. At its southern end, the PFZ splays into a horsetail formed by ENE-WSW reverse faults (Fig. 3C and 4C). Southdipping reverse faults form the north boundary of the Sierra Cabrera (Booth-Rea et al., 2004), locally affecting Quaternary sediments (Sanz de Galdeano, 1987), and north-dipping reverse faults constitute the southern edge of the Sierra (Keller et al., 1995). The CuaTeNeo (Cuantificiación de la Tectónica actual y Neotectónica) GPS nonpermanent network was installed in 1996 to quantify the deformation in the Eastern Betic Cordillera. The network consists of 15 monuments covering an area of $120 \times 50$ $\mathrm{km}$ in Murcia and Almería (Colomina et al., 1998; Khazaradze et al., 2007 and 2008). In the northern part of the GPS network, the stations placed westward of the AMF and the PFZ show insignificant motions with respect to the stable part of the Eurasian plate. The GPS sites placed close to coast, eastward of the AMF and the PFZ, move $1-1.5 \mathrm{~mm} / \mathrm{yr}$ toward the NNW revealing a strain accumulation (Echeverria et al., 2011; Frontera et al., 2011).

\section{The Campo de Dalías and the Almería-Níjar basin}

The Campo de Dalías and the Almería-Níjar basin are located at the boundary between the Alborán Sea and the Betic Cordillera. In both basins, the Tortonian and Pliocene marine sedimentary rocks, which belonged to the Northern Alborán basin, have emerged in Quaternary times (Fig. 5).

\subsection{Late Miocene tectonic structures}

The Carboneras fault zone (CFZ) is a major regional left-lateral fault that extends onshore along the AlmeríaNíjar basin (Bousquet and Montenant 1974; Ott d'Estevou and Montenant; 1985, Keller et al., 1995; Scotney et al., 2000; Faulkner et al., 2003) and continues offshore along the Almería Gulf in a NE-SW direction (Fig. 5; De Larouzière et al., 1988; Gràcia et al., 2006. The upper Miocene sediments, together with metamorphic and volcanic basement rocks, crop out along the highly deformed CFZ (Bousquet and Montenant 1974; Rutter et al., 1986; 


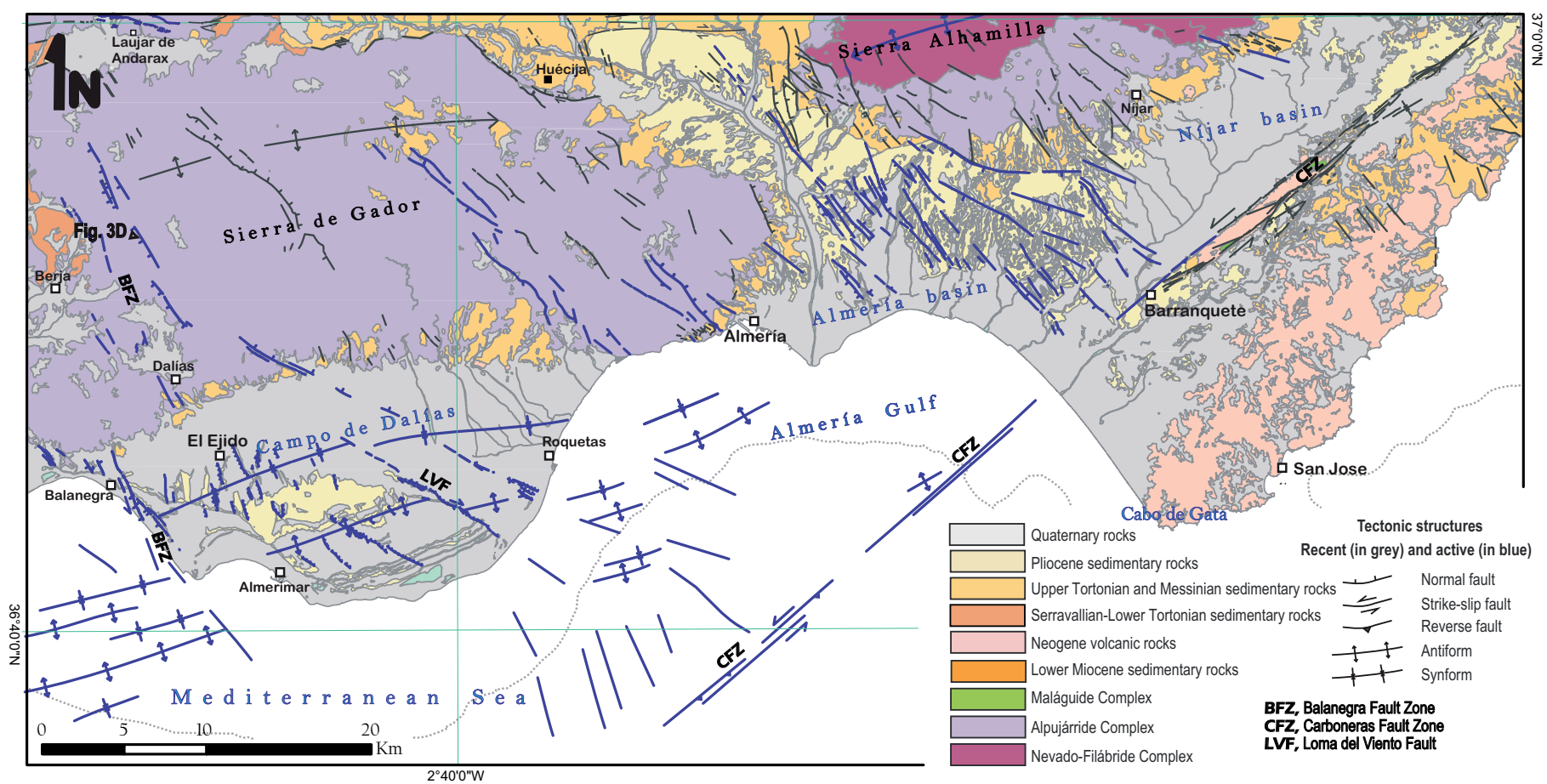

Fig. 5.- Geological map of the Campo de Dalías and the Almería/Níjar Basin with the traces of the recent (in grey) and active (blue) tectonic structures. The location of figure 3D is marked.

Fig. 5.- Mapa geológico del Campo de Dalías y de la Cuenca de Almería/Níjar con las trazas de las estructuras tectónicas recientes (en gris) y activas (en azul). La posición de la figura 3D está indicada.

Van de Poel, 1991; Keller et al., 1995). The nucleation of the crustal-scale CFZ is closely linked to the Miocene volcanism, which modified the thermal structure and the strength of the lithosphere (Pedrera et al., 2010b). Northwards of the CFZ, the sedimentary rocks are widely deformed by folds with a hundreds of meters amplitude and consistently showing an ENE-WSW strike onshore and offshore (Figs. 4B and 5). These folds deformed the sediments before the Messinian generating a cartographic unconformity between the highly folded upper Tortonian rocks and the less deformed post-Messinian sediments (Weijermars et al., 1985).

To the north, the highest reliefs in the area are linked to culminations on the hinge line of the Sierra Alhamilla and Sierra the Gádor antiforms, which have an ENE-WSW orientation, $10 \mathrm{~km}$ of maximum amplitude, and are 25 to $30 \mathrm{~km}$ long respectively, and more than $1300 \mathrm{~m}$ high. The lower Tortonian-Serravallian conglomerates and the upper Tortonian sediments that surround the ranges are folded, revealing the fold geometry and the age of the deformation. In the Sierra Alhamilla, the late Tortonian rocks $\operatorname{dip} 20^{\circ}$ in the southern slopes, yet are vertical or even overturned on the northern slopes as a consequence of the northward fold vergence and the activity of the E-W oriented high-angle reverse to right-lateral Lucainena fault zone (Weijermars et al., 1985; Sanz de Galdeano, 1989).
The Nijar basin is intensely deformed by high-angle dipping normal faults since the Late Miocene (MartínezDíaz and Hernández-Enrile, 2004; Marín-Lechado et al., 2005; Pedrera et al., 2006; Sanz de Galdeano et al., 2010). They have a consistent NNW-SSE to NW-SE strike. Although the normal faults have a widespread distribution, their presence predominates in western Níjar, extending toward the Tabernas basins and very locally toward the Sorbas basin. The Nijar basin depocenter is associated with this NW-SE oriented normal fault activity. The maximum sedimentary thickness, established from gravity data, reaches more than $1 \mathrm{~km}$ in the western sector of the basin (Pedrera et al., 2006). The fault surfaces dip towards the SW and usually deform the Tortonian and Messinian sediments, showing variable geometries from listric to domino-like systems. To the south-eastern part of the Almería Níjar basin, NW-SE normal faults dipping mainly to the NE deform the Pliocene sediments, sometimes showing syn-sedimentary features (Marín-Lechado et al., 2005; Pedrera et al., 2006).

\subsection{Active tectonic structures}

ENE-WSW open to gentle N-vergent folds affect the Pliocene and Quaternary sediments that extend along the continental shelf of the Almería Gulf, the Campo de 
Dalías (Marín-Lechado et al., 2006) and the Níjar basin (Fig. 5; Sanz de Galdeano, 1989; Huibregtse et al., 1998; Pedrera et al., 2006). These folds indicate the continuity of the contractional deformation after the major Messinian unconformity. In addition, normal to normal-oblique faults deform alluvial sediments up to the Pliocene and the Quaternary, generating fault scarps. In the AlmeríaNíjar basin, NNW-SSE to NW-SE normal faults are responsible for high slopes and sharp topography in the western part of the Sierra Alhamilla antiform and deform its southern limb. Therefore, from Gergal to Cabo de Gata, they control the Andarax valley geometry and the rectilinear coast line (e.g., Martínez-Díaz and Hernández-Enrile, 2004; Marín-Lechado et al., 2005; Pedrera et al., 2006; Sanz de Galdeano et al., 2010). From a geomorphological point of view, abrupt changes in the channels slope are probably associated to the activity of these normal faults (Giaconia, 2012).

Onshore recent tectonic activity of the CFZ is well observed near Barranquete, in the SW sector, where N30 $45^{\circ} \mathrm{E}$ subvertical left-lateral fault surfaces deform Quaternary sediments (e.g., Boorsma, 1992; Pedrera et al., 2006). There, detailed geochronological and paleoseismic studies have been carried out (Moreno, 2011). Slip-rates, paleoseismologic, and seismic potential behaviour of the CFZ derived from onshore-offshore results have been recently described in detail by Moreno (2011) . A GPS station on the southern fault block is moving $1.5 \pm 0.7 \mathrm{~mm} /$ yr toward the NNE with respect to northward stations. This can be interpreted as being mainly caused by the left-lateral strike slip motion along the CFZ (Khazaradze et al., 2010).

The Campo de Dalías is widely deformed by subvertical oblique-slip faults that have directions between NW-SE and WNW-ESE and that have been active since the Pleistocene (Martínez-Díaz, 1998; Martínez-Díaz and Hernández-Enrile, 2004; Marín-Lechado et al., 2004, 2005; Pedrera et al., 2012). The Balanegra fault zone extends from the western end of the Sierra de Gádor toward the Alborán Sea, controlling the western termination of the Sierra de Gádor antiform and the NW-SE oriented straight morphology of the coast line (Figs. 3D and 5; Martínez-Díaz and Hernández-Enrile, 2004; MarínLechado et al., 2005 and 2010; Fernández-Ibáñez et al., 2006). Other prominent fault is the WNW-ESE oriented Loma del Viento fault (Figs. 3D and 5), which deforms the central part of the Campo de Dalías with dextral-normal kinematics since Pleistocene (Marín-Lechado et al., 2004; Martínez-Díaz and Hernández-Enrile, 2004; Pedrera et al., 2012). The Loma del Viento fault is formed by six onshore segments and some of them are hard-linked
(Pedrera et al., 2012). Fault slip enhances toward the linkage sectors with an estimated long-term slip rate of $0.07 \pm 0.03 \mathrm{~mm} / \mathrm{yr}$ since the Pleistocene (Fig. 5; Pedrera et al., 2012). The normal to normal-oblique faults continue toward the Alborán Sea, as deduced from NW-SE trending lineaments detected by bathymetric studies (Fig. 5; Gràcia et al., 2006).

A non-permanent GPS network was installed in the Campo de Dalías to control the crustal deformation associated with active folds and faults. GPS measurements were made in 2006 and 2011, and the data are being processed. In addition, two precision levelling profiles were installed along the southern part of the Balanegra fault zone and measured in 2006, 2007, 2009, and 2010 to estimate the short-term fault-slip rate (Marín-Lechado et al., 2010).

\section{Seismicity and Earthquake Sources}

The sector of the Betic Cordillera addressed in this paper is affected by distributed seismicity of low to moderate magnitude, which is limited to the upper crust (e.g., Stich et al., 2003, 2010; Fernández-Ibáñez and Soto, 2008). Earthquakes larger than Mw 5 rarely occur (Table 1). These major earthquakes can cautiously be associated with possible source faults, on the basis of damage descriptions in the cases of pre-instrumentally registered events and the estimated location and source analysis derived from the moment tensor solution in the case of the most recent earthquakes (Table 1). In the Campo de Dalías and surrounding sectors, large events occurred close to the village of Dalías (August 25, 1804, with felt intensity VIII-IX in the scale EMS-98 used throughout this paper, and $\mathrm{Mw} 6.4$ macroseismic magnitude) and close to Adra, where a Mw 6.1 earthquake and Mw 5.5 aftershock occurred on June 16, 1910. The source parameters of the main Adra shock was established after analysing six analogue seismogram recordings $\left(\mathrm{M}_{0}=1.50 \cdot 10^{-18}\right.$ $\mathrm{Nm}, \mathrm{Mw}=6.1$, oblique strike-slip event at $16 \mathrm{~km}$ in depth; Stich et al., 2003). Recently, two related events occurred to the south of Berja (December 23, 1993, Mw 5.3, $\mathrm{m}_{\mathrm{bL}}$ ), and of Guardias Viejas (January 4, 1994, Mw 4.9). Both reveal strike-slip, slightly oblique fault plane solutions with a $\mathrm{N} 120^{\circ} \mathrm{E}$ oriented dextral nodal plane (Stich et al., 2001), very similar to that found for the June 16, 1910 Adra earthquake. Stich et al. (2001) analysed the complete 1993-1994 seismic series and later seismicity in the area up to 1998 , recognizing 39 multiplet clusters with $\mathrm{N} 120-130^{\circ} \mathrm{E}$ and $\mathrm{N} 60-70^{\circ} \mathrm{E}$ lineaments. These earthquakes could be assigned to the Balanegra fault zone (Marín-Lechado et al., 2005), which is formed by $\mathrm{N} 120^{\circ} \mathrm{E}$ 


\begin{tabular}{|c|c|c|c|c|c|c|}
\hline Date & $\begin{array}{c}\text { Latitude } \\
(\mathrm{N})\end{array}$ & $\begin{array}{c}\text { Longitude } \\
\text { (W) }\end{array}$ & $\begin{array}{c}\text { Intensity } \\
\text { (EMS-98 scale) }\end{array}$ & Magnitude & Location & Possible source \\
\hline $01 / 01 / 1406$ & 37.25 & 1.87 & VII-VIII & $\mathrm{M}_{\mathrm{S}} 5.0^{1}$ & Vera. Al & Palomares Fault \\
\hline $01 / 11 / 1487$ & 36.83 & 2.47 & VIII & $\mathrm{M}_{\mathrm{S}} 5.4^{1}$ & Almería & NW-SE normal faults \\
\hline $09 / 11 / 1518$ & 37.23 & 1.87 & VIII-IX & $\mathrm{M}_{\mathrm{S}} 6.0^{1}$ & Vera. Al & Palomares Fault \\
\hline $22 / 09 / 1522$ & 36.97 & 2.67 & VIII-IX & $\mathrm{M}_{\mathrm{w}} 6.5^{2}$ & $\begin{array}{l}\text { W Alhama } \\
\text { de Almería. Al }\end{array}$ & Carboneras Fault; NW-SE normal faults \\
\hline $31 / 12 / 1658$ & 36.83 & 2.47 & VIII & $\mathrm{M}_{\mathrm{S}} 5.4^{1}$ & Almería & NW-SE normal faults \\
\hline$---/---/ 1686$ & 36.85 & 2.95 & VI-VII & $\mathrm{M}_{\mathrm{S}} 4.5^{1}$ & Berja. Al & Balanegra Fault Zone -western Gádor \\
\hline $25 / 08 / 1804$ & 36.77 & 2.83 & VIII-IX & $\mathrm{M}_{\mathrm{w}} 6.4^{2}$ & Dalías. Al & Balanegra or Loma del Viento Fault \\
\hline 25/08/1804* & 36.77 & 2.83 & VII & $\mathrm{M}_{\mathrm{S}} 4.7^{1}$ & Dalías. Al & Balanegra or Loma del Viento Fault \\
\hline 29/08/1804* & 36.77 & 2.83 & VII & $\mathrm{M}_{\mathrm{S}} 4.7^{1}$ & Dalías. Al & Balanegra or Loma del Viento Fault \\
\hline $10 / 06 / 1863$ & 37.37 & 1.93 & VI-VII & $\mathrm{M}_{\mathrm{s}} 4.5^{1}$ & Huércal-Overa & $\begin{array}{l}\text { Reverse faults Huércal Overa (South termination } \\
\qquad \text { AMF) }\end{array}$ \\
\hline $11 / 06 / 1894$ & 37.12 & 2.67 & VII & $\mathrm{M}_{\mathrm{S}} 4.7^{1}$ & Nacimiento. Al & NW-SE normal faults \\
\hline $13 / 05 / 1895$ & 37.00 & 1.90 & VI-VII & $\mathrm{M}_{\mathrm{S}} 4.5^{1}$ & Carboneras. Al & Palomares Fault \\
\hline $16 / 06 / 1910$ & $\begin{array}{l}36.67 \\
36.84^{2} \\
\end{array}$ & $\begin{array}{l}3.37 \\
3.00^{2} \\
\end{array}$ & VIII & $\begin{array}{l}M_{W} 6.1^{3} \\
M_{W} 6.7^{2}\end{array}$ & Adra. Al & Balanegra Fault Zone \\
\hline $16 / 06 / 1910^{*}$ & 36.67 & 3.37 & VII & $M_{w} 5.5^{3}$ & Adra. Al & Balanegra Fault Zone \\
\hline $22 / 04 / 1912$ & 37.03 & 2.95 & VII & $\mathrm{M}_{\mathrm{S}} 4.7^{1}$ & Ocaña. Al & \\
\hline 05/03/1932 & $\begin{array}{l}37.42 \\
37.51^{2} \\
\end{array}$ & $\begin{array}{l}.45 \\
2.45^{2} \\
\end{array}$ & VIII & $\begin{array}{c}\mathrm{m}_{\mathrm{D}} 4.8 \\
\mathrm{M}_{\mathrm{W}} 5.7^{2}\end{array}$ & Lúcar. Al & Lúcar-Somontín Faults \\
\hline $16 / 03 / 1972$ & 37.42 & 2.24 & VII & $\mathrm{m}_{\mathrm{bLg}} 4.8$ & NW Partaloa. Al & Reverse faults eastern Almanzora \\
\hline $13 / 09 / 1984$ & 36.98 & 2.34 & $\mathrm{~V}$ & $\mathrm{~m}_{\mathrm{bLg}} 5.0$ & SE Tabernas. Al & \\
\hline $23 / 12 / 1993$ & 36.78 & 2.94 & VII & $\mathrm{m}_{\mathrm{bLg}} 5.0$ & S Berja & Strike-slip, slightly oblique Balanegra Fault \\
\hline 04/01/1994* & 36.57 & 2.82 & VII & $\mathrm{m}_{\mathrm{bLg}} 4.9$ & N Alborán & Strike-slip slightly oblique Balanegra Fault \\
\hline $04 / 02 / 2002$ & 37.09 & 2.53 & V & $\begin{array}{l}\mathrm{m}_{\mathrm{bLg}} 5.1 \\
\mathrm{M}_{\mathrm{w}} 4.6\end{array}$ & S Gergal. Al & NW-SE normal faults. \\
\hline
\end{tabular}

* Foreshock;

1 From maximum intensity, using the D'Amico et al. (1999) relationship; 2 Mezcua et al. (2004), using the procedure by Bakun and Wentworth (1997); 3 Stich et al. (2003a)

Table 1.- Significant historic and instrumental earthquakes in the study area.

Tabla 1.- Terremotos históricos e instrumentales en la zona de estudio.

to $\mathrm{N} 160^{\circ} \mathrm{E}$ trending oblique-slip segments. Instrumental seismicity is concentrated in the basement at the northwestern end of the fault zone, where the 2002 Gergal earthquake Mw 4.7 was located (Sanz de Galdeano et al., 2010). In addition, the 1894 Nacimiento earthquake (VII) could be tentatively associated with these normal faults. The 1522 Almería earthquake (VIII-IX), for which the exact epicentre is unknown, has been associated with the offshore segment of the CFZ (Reicherter and Hübscher, 2006). Vera was destroyed in 1518 (VIII-IX) by an earthquake that could be hosted by the left-lateral Palomares fault (Bousquet, 1979; Weijermars, 1987). Toward the north, two moderate earthquakes were registered in the Almanzora corridor: the April 5, 1932 Lúcar earthquake (VIII, $\mathrm{m}_{\mathrm{D}}$ 4.8) and the April 16, 1972 NW Partaloa earthquake (VII, $\mathrm{m}_{\mathrm{bLg}}$ 4.8). The Lúcar earthquake could tentatively be associated with the Lúcar and Somontín fault zone, which extends from the Almanzora basin towards the Sierra de la Estancias, crossing the village of Lúcar. The village of Partaloa is located above a sector deformed by active ENE-WSW reverse faults and associated folds (Pedrera et al., 2007, 2009a, 2009c).

\section{Discussion and Conclusions}

This work compiles the available information on the late Miocene to Quaternary faults and folds in the centraleastern Internal Zones of the Betic Cordillera. Some of these features have probably been the source of moderate-sized earthquakes throughout history and therefore are potential sources of future earthquakes.

\subsection{Late Miocene geodynamic evolution}

Regarding the evolution of the tectonic structures over time, folding started in the present position of the Sierra 

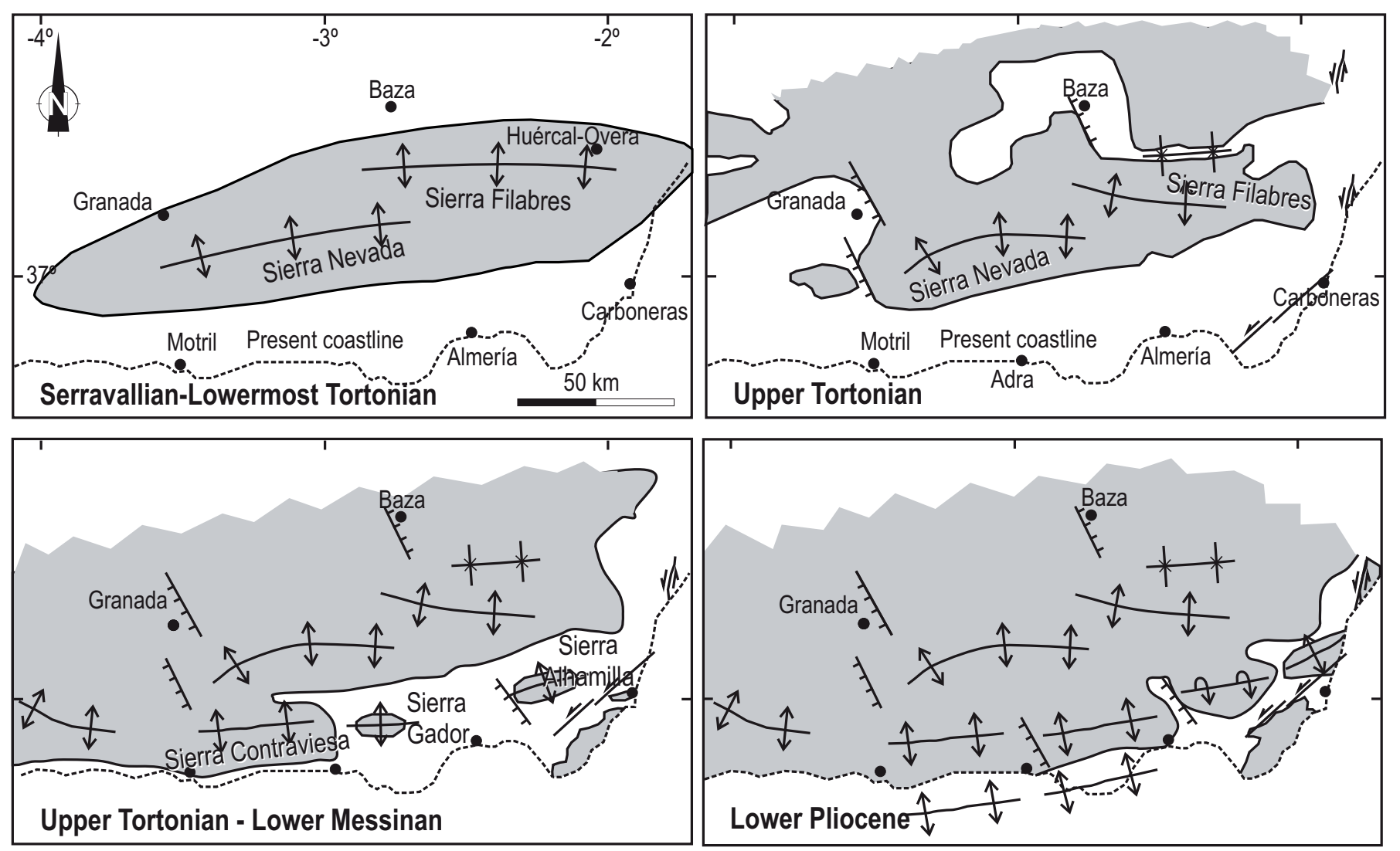

Fig. 6.- Paleogeographic and tectonic evolution of the central-eastern Betic Cordillera from the Serravallian-lowermost Tortonian onward. Evolution of the emergent land reconstructed from the facies distributions in the Neogene basins (Braga et al., 2003). Note that the progressive emergence of the sierras coincides with the traces of the antiforms.

Fig. 6-. Reconstrucción paleogeográfica y evolución tectónica del sector central y oriental de la Cordillera Bética desde el Serravaliense-Tortoniense inferior. La distribución espacial y temporal de tierras emergidas/sumergidas se estableció a partir del análisis de facies (modificado de Braga et al., 2003). Es preciso remarcar la coincidencia entre la posición de las sierras y la traza de las antiformas.

Nevada and Sierra de Los Filabres during the Serravallian-early Tortonian (Fig. 6). Therefore, stratigraphic and sedimentological studies indicate that a large E-W island started to emerge there at this time (Braga et al., 2003). These large-scale antiforms underwent progressive lateral growth from east to west, folding the previous extensional detachments and therefore favouring the final exhumation of the Nevado-Filábride rocks. Fission-track analyses revealed that cooling to nearly surface temperatures occurred first in the Sierra de Los Filabres during the mid-Serravallian (12 Ma) and later in Sierra Nevada, located to the west (9-8 Ma; Johnson et al. 1997). The erosion of these ranges supplied sediments to the nearby basins. Progressive unconformities found in the Serravallian-lower Tortonian conglomerate formation located in the Almanzora corridor are coeval with the Sierra de Los Filabres antiform growth. Since the late Tortonian, folding continues and propagates northwards (Sierra de Las Estancias) and southwards (the Sierra de Gádor, the Sierra Alhamilla and the Sierra Cabrera). In addition, the Almanzora corridor, the Huércal-Overa basin, the Al- pujarran corridor, and the Tabernas basin acquired their elongate shape.

The origin of the E-W to ENE-WSW trending largescale open folds is still under debate. The folds have been interpreted as caused by isostatic rebound in response to extensional denudation along the regional extensional detachments (e.g., Martínez-Martínez et al., 2002; Augier et al., 2005; Meigninger and Vissers, 2006). Alternatively, we consider them as contractional folds developed above upper-crustal detachments developed in a collisional framework (e.g., Weijermars et al., 1985; Montenat and Ott d'Estevou, 1990; Sanz de Galdeano and Vera, 1992; Martínez-Martínez et al., 1995; Galindo-Zaldívar et al., 2003; Sanz de Galdeano and Alfaro, 2004; Pedrera et al., 2009b). In any case, these folds contribute to the uplift of the northern boundary of the Alborán Basin gradually disconnecting the now emerged intramontane basins (Comas et al., 1992, 1999) and inducing the development of the present-day relief (Fig. 6; Braga et al., 2003; Sanz de Galdeano and Alfaro, 2004. In addition, melts in the deep crust and middle to upper Miocene volcanism also 
conditioned the relief and the deformation mode (Duggen et al., 2008; Soto et al., 2008).

Coevally to large-scale open fold development, E-W transpressive right-lateral and reverse faults nucleated along the Alpujarra, the Tabernas, and the Sorbas basins while the NNE-SSW/NE-SW left-lateral Palomares and Carboneras fault zones occurred in the easternmost part of the cordillera (Fig. 6). Thus, the Polopos fault has been interpreted as a conjugate fault system to the Carboneras and Palomares left-lateral fault zones (Giaconia et al., 2012). Coeval to the relief growth, NW-SE to E-W normal and oblique slip normal faults developed.

During the Messinian, Pliocene and Quaternary, compression contributed to the progression of the moderate crustal thickening and to the regional progressive emersion of the marine basins with the final capture by the drainage network of the endorheic basins. Active folds caused the emersion of the northern Alborán Sea (MarínLechado et al., 2006). In addition, there was continued activity of some segments of the strike-slip faults. Moreover, normal and normal-oblique faults have remained active during the Quaternary to the present in this part of the cordillera.

\subsection{Active Tectonics}

The present study summarized the most prominent active faults of the central-eastern Internal Zones of the Betic Cordillera (from $3.1^{\circ} \mathrm{W}$ to $1.7^{\circ} \mathrm{W}$ and to the south of $37.525^{\circ} \mathrm{N}$ ) providing detailed maps of the fault and fold traces (Fig. 7). The Campo de Dalías and surrounding sectors are probably the sites with the greatest concentra-

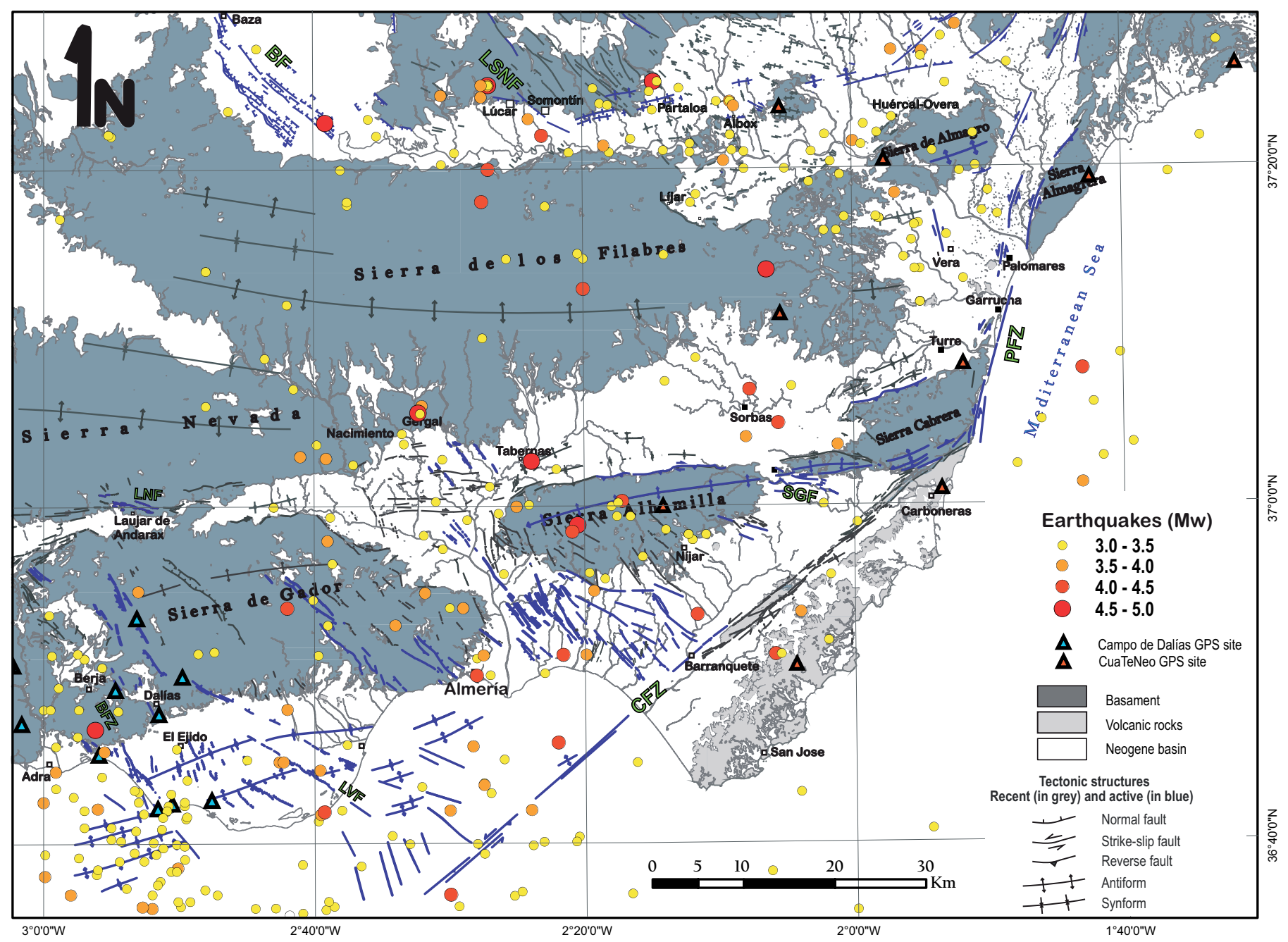

Fig. 7.- Seismotectonic map of the study area showing traces of recent and active tectonic structures and the location of the seismicity with $M_{w} \geq 3$ for the period 1926-2011 from the Instituto Geográfico Nacional catalogue (http//:www.ign.es). The non-permanent GPS sites of the networks CuaTeNeo and Campo de Dalías are marked.

Fig. 7.- Mapa sismotectónico del area de estudio con la traza de las principales estructuras tectónicas (recientes y activas) y la posición de la sismicidad $\mathrm{M}_{\mathrm{w}} \geq 3$ comprendida entre 1926-2011 (catalogo del IGN, Instituto Geográfico Nacional, http//:www.ign.es). Se ha incluido la posición (no permanente) de los GPS pertenecientes a las redes CuaTeNeo y Campo de Dalías. 
tion of large earthquakes during the recent history. Moderate-sized earthquakes (Mw 5.0 to 6.0-6.5) have occurred in this area at fairly regular intervals, in 1804, 1910, and 1993 probably associated to the Balanegra fault zone activity (Marín-Lechado et al., 2010). Despite the absence of clear historic earthquakes associated with the Loma del Viento fault, it is reasonable to consider it as a potential seismic fault (Pedrera et al., 2012). There, we have designed a multidisciplinary control of the potential earthquakes sources. We have mapped the active faults and folds in detail. In addition, we performed a 3D geological model by incorporating borehole and geophysical data to establish the geometry of the tectonic structures. The sector is monitored with a non-permanent GPS network and high-precision levelling profiles (Fig. 7). The geometric knowledge of these structures combined with geodetic measurements of tectonic-strain accumulation yield improved models of nucleation, linkage, and propagation of active faults, as well as their seismic implications.

The NW-SE trending Quaternary faults extending from Almería to the Tabernas basin and separating Sierra Alhamilla from Sierra de Gádor have related seismicity (Fig. 7). These NW-SE normal faults have higher seismic potential than does the E-W dextral system (the 2002, Mw 4.7 Gergal earthquake and the 1894 Nacimiento earthquake, VII).

Toward the north in the Almanzora corridor, the LúcarSomontín NW-SE to WNW-ESE trending Quaternary faults could also cautiously be considered as possible sources of moderate-magnitude seismicity (the April 5, 1932 Lúcar $m_{D} 4.8$ earthquake, VIII). Toward the east, between Albox and Partaloa, several small reverse faults and associated compressive structures deforming Quaternary alluvial and fluvial sediments (Fig. 7) have been described? The syn-folding fan geometry observed in the one of these structures (La Molata structure, Pedrera et al., 2009a) suggests a slow and progressive deformation from middle Pleistocene onward. They do not show scarps or erosive deposits, such as clastic wedges, indicative of abrupt deformation events related to earthquakes, suggesting that the La Molata structure is most likely connected with aseismic slip during Quaternary faultrelated fold growth. Nevertheless, some of these reverse fault segments could have associated moderate-sized events such as the April 16, 1972 NW Partaloa, $\mathrm{m}_{\text {bLg }} 4.8$ earthquake (VII). Regarding the proximity between the villages Lúcar and Partaloa, further seismic studies of the main shock parameters are necessary to identify viable source structures.

The PFZ is very favourably oriented $\left(\mathrm{N} 10-20^{\circ} \mathrm{E}\right.$ trend) with respect to the present-day stress field for left-lateral strike-slip displacement. The angle between the fault strike and the maximum principal stress is around $30^{\circ}$. Therefore, this fault probably nucleates moderate-sized earthquakes (1518 Vera earthquake). Unlike the Palomares fault, the CFZ is almost orthogonal to the presentday maximum horizontal compressive stress. Although not very suitably oriented to act as a strike-slip fault, it could act as a high-angle reverse or reverse-oblique fault despite its sub-vertical geometry. Paleoseismic data, high resolution seismic profiles and sediment coring indicate Quaternary activity of some fault segments (Reicherter and Hübscher, 2006; Moreno et al., 2009). The ongoing GPS results derived from the CuaTeNeo network will decisively contribute to understand the relationship between the strain accumulation and seismic potential of the Carboneras and Palomares fault zones (Fig. 7).

\section{Acknowledgements}

This study was supported by the projects TOPOIBERIA CONSOLIDER-INGENIO CSD2006-00041, CGL2010-21048, CGL-2008-03474-E, P09-RNM-5388 of the Spanish Ministry of Science and Education, project CGL-2011-29920, as well as by Research Groups RNM148, RNM-325, and RNM-370 of the Junta de Andalucía Regional Government. We thank Carlos Sanz de Galdeano for constructive reading of the manuscript. We appreciate the revisions of Reinoud Vissers and Pedro Alfaro that notably improved the quality of the paper.

\section{References}

Aldaya, F., Campos, J., García-Dueñas, V., González-Lodeiro, F., Orozco, M. (1984): El contacto Alpujárrides-Nevado-Filábrides en la vertiente meridional de Sierra Nevada. Implicaciones tectónicas. In: J. López Ruiz (ed.), El borde Mediterráneo español: evolución del orógeno bético y geodinámica de las depresiones neógenas, CSIC-Universidad de Granada, Granada: 18-20.

Alfaro, P., Delgado, J., Sanz de Galdeano, C., Galindo-Zaldívar, J., García-Tortosa, F.J., López Garrido, A.C., López Casado, C., Marín, C., Gil, A.J., Borque, M.J. (2008): The Baza Fault: a major active extensional fault in the central Betic Cordillera (south Spain). International Journal of Earth Sciences 97, 1353-1365. doi: 10.1007/ s00531-007-0213-z

Andrieux, J., Fontbote, J.M., Mattauer, M. (1971): Sur un modele expiicatif de 1'Arc de Gibraltar. Earth Planet. Sci. Lett. 12, 191-198.

Argus, D. F., Gordon, R. G., DeMets, C., Stein, S. (1989): Closure of the Africa-Eurasia-North America plate motion circuit and tectonics of the Gloria fault. J.Geophys. Res. 94, 5585-5602.

Augier, R. (2004): Evolution tardi-orogénique des Cordilères Bétiques (Espagne): Apports d'un étude intégrée. $\mathrm{PhD}$ Thesis, Univ. Pierre et Marie Curie, Paris: 400 pp.

Augier, R., Jolivet, L., Robin, C. (2005): Late Orogenic doming in the eastern Betic Cordilleras: Final exhumation of the NevadoFilábride complex and its relation to basin genesis. Tectonics 24, TC4003. doi:10.1029/2004TC001687. 
Bakun, W. H., and Wentworth, C. M. (1997): Estimating earthquake location and magnitude from seismic intensity data. Bulletin of the Seismological Society of America 87, 15021521.

Biju Duval, B., Dercourt, J., Le Pichon, X. (1977): From the Tethys to the Mediterranean seas: a plate tectonic model of the evolution of the western alpine system. In: B. Biju DuvaI and L. Montadert (ed.), Structural History of the Mediterranean Basin, Technip, Paris: 143-164.

Booth-Rea, G, Azañón, J.M., Azor, A., García-Dueñas, V. (2004): Influence of strike-slip fault segmentation on drainage evolution and topography. A case study: the Palomares Fault Zone (southeastern Betics, Spain). Journal of Structural Geology 26, 1615-1632. doi: 10.1016/j.jsg.2004.01.007

Booth-Rea, G., Azañón, J.M., García-Dueñas, V., Augier, R. (2003): Uppermost Tortonian to Quaternary depocentre migration related with segmentation of the strike-slip Palomares Fault Zone, Vera basin, SE Spain. Comptes Rendus Geoscience 335, 751-761. doi:10.1016/S1631-0713(03)00121-4

Boorsma, L.J. (1992): Syn-tectonic sedimentation in a Neogene strike-slip basin containing a stacked Gilbert-type delta (SE Spain). Sed. Geol. 81: 105-123.

Bousquet, J.C. (1979): Quaternary strike-slip faults in southeastern Spain. Tectonophysics 52, 277-286.

Bousquet, J.C., Montenat, C. (1974): Présence de décrochements Nord-Est, Sud-Ouest plioquaternaires dans les Cordillères bétiques orientales (Espagne). Extension et signification générale. C. $R$. Acad. Sci. 278, 2617-2620.

Bousquet, J.C., Phillip, H. (1976): Observations microtectóniques sur la compresion nord-sud quaternaire des Cordillères bétiques orientales (Espagne meridionale-Arc de Gibraltar). Bull Soc. Geol. France 28, 711-724.

Braga, J.C., Martín, J.M., Quesada, C. (2003): Patterns and average rates of late Neogene-Recent uplift of the Betic Cordillera, SE Spain. Geomorphology 50, 3-26.

Briend, M. (1981): Evolution morpho-tectonique du bassin Néogène de Huércal Overa (Cordilleres betiques orientales, Espagne). Ph. Thesis, Inst. Géol., Albertde-Lapparent. Paris. Doc. Trav. IGAL: 208 pp.

Briend, M., Montenat, C., Ott d'Estevou, P. (1990): Le Bassin de Huércal Overa. In: C. Montenat (ed.), Les Bassins Néogeènes du Domaine Beétique Orientale (Espagne). Documents et Travaux du Institut Géologique Albert-de-Lapparent 12-13, Paris: 239-259.

Chalouan, A., Michard, A. (2004): The Alpine Rif Belt (Morocco): a case of mountain building in a subduction-subduction-transform fault triple junction. Pure Appl. Geophys. 161, 489-519. doi: 10.1007/s00024-003-2460-7

Colomina, I., Fleta, J., Giménez, J., Goula, X., Masana, E., Ortiz, M. À., Santanach, P., Soro, M., Suriñach, E., Talaya, J., Térmens, A. (1998): The CuaTeNeo GPS network to quantify horizontal movements in the Southeastern part of the Iberian Peninsula. $1^{a}$ Asamblea Hispano-Portuguesa de Geodesia y Geofísica, $9^{a}$ Asamblea Nacional de Geodesia y Geofísica, Aguadulce, Almería: 199-204.

Comas, M.C., García-Dueñas, V., Jurado, M.J. (1992): Neogene tectonic evolution of the Alborán Basin from MCS data. Geo-Mar. Lett. 12, 157-164.

Comas, M.C., Platt, J.P., Soto, J.I., Watts, A.B. (1999): The origin and tectonic history of the Alborán Basin: Insights from ODP Leg 161 results. In: Zahn, R., Comas, M.C., Klaus, A. (eds), Proceedings of the Ocean Drilling Program, Scientific Results 161, College Station, TX (Ocean Drilling Program), 555-580.

D Amico,V., D. Albarello, and Mantovanil, E. (1999): A distributionfree analysis of magnitud-intensity relationships: an application to the Mediterranean region. Phys. Chem. Earth 24,517-521.
De Larouzière, F.D., Bolze, J., Bordet, P., Hemandez, J., Montenat, Ch., Ott d'Estevou, P. (1988): The Betic segment of the lithospheric Trans-Alborán shear zone during the Late Miocene. Tectonophysics $152,41-52$.

DeMets, C., Gordon, R.G., Argus, D.F., Stein, S. (1990): Current plate motions. Geophysical Journal International 101, 425-478.

DeMets, C., Gordon, R.G., Argus, D.F., Stein, S. (1994): Effect of recent revisions to the geomagnetic reversal time scale on estimates of current plate motions. Geophys. Res. Lett. 21, 2191-2194.

Duggen, S., Hoernle, K., Klügel, A., Geldmacher, J., Thirlwall, M., Hauff, F., Lowry, D., Oates, N. (2008): Geochemical zonation of the Miocene Alborán Basin volcanism westernmost Mediterranean, geodynamic implications. Contrib. Mineral. Petrol. 156, 577-593. doi:10.1007/s00410-008r-r0302-4.

Echeverria, A., Khazaradze, G., Garate, J., Asensio, E., Masana, E., Suriñach, E. (2011): Present-day GPS crustal deformation rates in the Eastern Betics (SE. Spain). Geophysical Research Abstracts 13, EGU2011, EGU General Assembly 2011, Viena: -8005

Fadil, A., Vernant, P., McClusky, S., Reilinger, R., Gomez, F., Ben Sari, D., Moura- bit, T., Feigl, K.L., Barazangi, M. (2006): Active Tectonics of the western Mediterranean: GPS evidence for roll back of a delaminated subcontinental lithospheric slab beneath the Rif Mountains, Morocco. Geology 34, 529-532, doi:10.1130/ G22291.1.

Faulkner, D.R., Lewis, A.C., Rutter, E.H. (2003): On the internal structure and mechanics of large strike-slip fault zones: field observations of the Carboneras fault in southeastern Spain. Tectonophysics 367, 235-251.

Fernández-Ibáñez, F., Pérez-Peña, J.V., Azañón J.M., González-Lodeiro, F. (2006): Morphological and structural characterization of western Sierra de Gádor (Betic Cordillera). Geogaceta 40, 71-76.

Fernández-Ibáñez, F., Soto, J.I., Zoback, M.D., Morales, J. (2007): Present-day stress field in the Gibraltar Arc (western Mediterranean). J. Geophys. Res. 112, B08404, doi:10.1029/2006JB004683.

Fernández-Ibáñez, F., Soto, J.I. (2008): Crustal rheology and seismicity in the Gibraltar Arc western Mediterranean. Tectonics 27, TC2007, doi:10.1029/2007TC002192.

Frontera, T., Concha, A., Blanco, P., Echeverria, A., Goula, X., Arbiol, R., Khazaradze, G., Pérez, F., Suriñach, E. (2011): DInSAR coseismic deformation of the May $2011 \mathrm{Mw} 5.1$ Lorca earthquake (Southern Spain). Solid Earth Discussions 3, 2, 963-974.

Galindo Zaldívar, J. (1986): Etapas de fallamiento neógenas en la mitad occidental de la depresión de Ugijar (Cordilleras Béticas). Estudios Geológicos 42, 1-10.

Galindo-Zaldívar, J., Gil, A.J., Borque, M.J., González-Lodeiro, F, Jabaloy, A., Marín-Lechado, C., Ruano, P., Sanz de Galdeano, C. (2003): Active faulting in the internal zones of the central Betic Cordilleras (SE, Spain). Journal of Geodynamics 36, 239-250. doi:10.1016/S0264-3707(03)00049-8

García-Dueñas, V., Martínez-Martínez, J.M. (1988): Sobre el adelgazamiento mioceno del Dominio de Alborán: El despegue de los Filabres (Béticas orientales). Geogaceta 5, 53-55.

García-Meléndez, E., 2000. Geomorfología y Neotectónica del Cuaternario de la cuenca de Húercal-Overa y corredor del Almanzora. Análisis y Cartografia mediante Teledetección y SIG. Unpublished $P h D$ Thesis. Universidad de Salamanca, Salamanca: 528 pp.

García-Meléndez, E., Goy, J.L., Zazo, C. (2003): Neotectonic and Plio-Quaternary landscape development within the eastern HuércalOvera Basin (Betic Cordilleras, southeastern Spain). Geomorphology $50,111-133$.

García-Meléndez, E., Goy, J.L., Zazo, C. (2004). Quaternary tectonic activity in the Húercal-Overa Basin (Almería, Southeast Spain): deformations associated with the Albox fault. Geogaceta 36, 63-66. 
García-Tortosa, F.J., Alfaro, P., Galindo-Zaldívar, J., Gibert, L., López Garrido, A.C., Sanz de Galdeano, C., Ureña, M. (2008): Geomorphologic evidence of the active Baza fault (Betic Cordillera, South Spain). Geomorphology 97, 374-391. doi:10.1016/j.geomorph.2007.08.007,

García-Tortosa, F.J., Sanz de Galdeano, C. (2007): Evidencias geomorfológicas de actividad tectónica cuaternaria en el frente montañoso del borde sur de Sierra Nevada: la falla normal de Laujar de Andarax. Cuaternario y Geomorfología 21, 101-112.

Giaconia, F., Booth-Rea, G., Martínez-Martínez, J. M., Azañón, J. V. Pérez-Peña., M. Pérez-Romero J., Villegas, I. (2012): Geomorphic evidence of active tectonics in the Sierra Alhamilla (eastern Betics, SE Spain). Geomorphology 145-146, 90-106. doi: 10.1016/j. geomorph.2011.12.043.

Goy, J.L., Zazo, C. (1986): Synthesis of the Quaternary in the Almería littoral, neotectonic activity and its morphologic features, Eastern Betics, Spain. Tectonophysics 130, 259-270.

Gràcia, E., Pallàs, R., Soto, J. I., Comas M., Moreno X., Masana, E., Santanach P., Diez S., García, M., Dañobeitia, J., HITS scientific party. (2006): Active faulting offshore SE Spain (Alborán Sea): Implications for earthquake hazard assessment in the Southern Iberian Margin. Earth and Planetary Science Letters 241, 734-749. doi:10.1016/j.eps1.2005.11.009

Groupe de Recherche Neotectonique (1977): L'histoire tectonique récente (Tortonien á Quaternaire) de l'Arc de Gibraltar: résultats de I'analyse structurale en Espagne. Bull Soc. Geol. France 7.

Huibregtse, P., Alebeek, H.V., Zaal, M., Biermann, C. (1998): Paleostress analysis of the northern Níjar and southern Vera basins: constraints for the Neogene displacement history of major strikeslip faults in the Betic Cordilleras, SE Spain. Tectonophysics 300, 79-101.

Jabaloy, A., Galindo Zaldívar, J., González Lodeiro, F. (1992): The Mecina Extensional System: Its relation with the Post-Aquitanian piggy-back basins and the paleostresses (Betic Cordilleras, Spain). Geo-Mar. Lett. 12, 96-103.

Jabaloy, A., Galindo-Zaldívar, J., González-Lodeiro, F. (1993): The Alpujárride/Nevado-Filábride extensional shear zone (Betic Cordilleras, SE Spain). Journal of Structural Geology 15, 555-569.

Jonk, R., Biermann, C. (2002): Deformation in Neogene sediments of the Sorbas and Vera Basins (SE Spain): constraints on simple-shear deformation and rigid body rotation along major strike-slip faults. J. Struct. Geol. 24, 963-977.

Johnson, C., Harbury, N., Hurford A.J. (1997): The role of extension in the Miocene denudation of the Nevado-Filábride Complex, Betic Cordillera (SE Spain), Tectonics 16, 189-204.

Khazaradze, G., Asensio, E., Moreno, X., Masana, E. (2010): Presentday crustal motion along the Carboneras fault in the Betic Cordilleras, Spain. American Geophysical Union, Fall Meeting 2010, abstract, San Francisco, California: G22A-08

Khazaradze, G., Gárate, J., Suriñach, E., Davila, J.M., Asensio, E. (2008): Crustal deformation in south-eastern Betics from CuaTeNeo GPS network. GeoTemas 10, 1-4.

Khazaradze, G., Suriñach, E., Gárate, J., Davila J. M. (2007): Crustal deformation in Eastern Betics from CuaTeNeo GPS network. Geophysical Research Abstracts Vol. 9, EGU2007, EGU General Assembly 2007, Viena: 05314

Keller, J.V.A., Hall, S.H., Dart, C.J., McClay, K.R. (1995): The geometry and evolution of a transpressional strike-slip system: the Carboneras fault, SE Spain. J. Geol. Soc. London 152, 339-351.

Lonergan, L., White, N. (1997): Origin of the Betic-Rif mountain belt. Tectonics 16, 504-522.

Marín-Lechado, C.; Galindo-Zaldívar, J.; Gil, A.J.; Borque, M.J.; De Lacy, C.; Pedrera, A.; López-Garrido, A.C.; Alfaro, P.; García-
Tortosa, F.J.; Ramos, M.I.; Rodríguez-Caderot, G.; RodríguezFernández, J.; Ruiz-Costán, A.: Sanz De Galdeano, C. (2010): Levelling Profiles and a GPS Network to Monitor the Active Folding and Faulting Deformation in the Campo de Dalías (Betic Cordillera, Southeastern Spain). Sensors 10, 3504-3518. doi:10.3390/ s100403504

Marín-Lechado, C., Galindo-Zaldívar, J., Rodríguez-Fernández, L. R., González-Lodeiro, F. (2004): Faulted hybrid joints: an example from the Campo de Dalías (Betic Cordilleras, Spain). Journal of Structural Geology 26, 2025-2037. doi:10.1016/j.jsg.2004.03.006

Marín-Lechado, C., Galindo-Zaldívar, J., Rodríguez-Fernández, L.R., Pedrera A. (2006): Mountain front development by folding and crustal thickening in the Internal Zone of the Betic Cordillera-Alborán Sea Boundary. Pure Appl. Geophys. 164, 1-21, doi: 10.1007/ s00024-006-0157-4.

Marín-Lechado, C., Galindo-Zaldívar, J., Rodríguez-Fernández, L. R., Serrano I., Pedrera, A. (2005): Active faults, seismicity and stresses in an internal boundary of a tectonic arc (Campo de Dalías and Nijar, southeastern Betic Cordilleras, Spain). Tectonophysics 396, 81-96.

Martín-Algarra, A. (1987): Evolution geológica alpina del contacto entre las Zonas Internas y las Zonas Externas de la Cordillera Bética (Sector Occidental). Ph.D. Thesis. Universidad de Granada, Granada: 1368 pp.

Martínez-Díaz, J.J. (1998): Neotectónica y Tectónica Activa del sector centrooccidental de Murcia y Sur de Almería, Cordillera Bética (España). Ph.D. Thesis, Universidad Complutense de Madrid, 466 p.

Martínez-Díaz, J.J. (2002): Stress field variation related to fault interaction in a reverse oblique-slip fault: the Alhama de Murcia fault, Betic Cordillera, Spain. Tectonophysics 356, 291-305.

Martínez-Díaz, J.J., Hernández-Enrile, J.L. (2004): Neotectonics and morphotectonics of the southern Almería region (Betic CordilleraSpain) kinematic implications. Int. J. Earth Sci. 93, 189-206. doi: 10.1007/s00531-003-0379-y.

Martínez-Díaz, J.J., Masana, E. Ortuno, M. (2012): Active Tectonics of the Alhama De Murcia Fault, Betic Cordillera, Spain. Journal of Iberian Geology doi.: $x x x x x x x x$

Martínez-Martínez, J.M. (2006): Lateral interaction between metamorphic core complexes and less-extended, tilt-block domains: the Alpujarras strike-slip transfer fault zone (Betics, SE Spain). Journal of Structural Geology 28, 602-620. doi: 10.1016/j.jsg.2006.01.012.

Martínez-Martínez, J. M., Azañón J. M. (1997): Mode of extensional tectonics in the southeastern Betics (SE Spain): Implications for the tectonic evolution of the peri-Alborán orogenic system, Tectonics 16, 205-225.

Martínez-Martínez, J.M., Booth-Rea, G., Azañón, J.M., Torcal, F. (2006): Active transfer fault zone linking a segmented extensional system (Betics, southern Spain): Insight into heterogeneous extensión driven by edge delamination. Tectonophysics 422, 159-173. doi:10.1016/j.tecto.2006.06.001.

Martínez-Martínez J.M., Soto J.I., Balanyá J.C. (1995): Large scale structures in the Nevado-Filábride complex and crustal seismic fabrics of the deep reflection seismic profile ESCI-Béticas 2. Revista de la Sociedad Geológica de España 8, 477-489.

Martínez-Martínez, J.M., Soto, J.I., Balanyá, J.C. (2002): Orthogonal folding of extensional detachments: structure and origin of the Sierra Nevada elongated dome (Betics, SE Spain). Tectonics 21, 1012, doi:10.1029/2001TC001283.

Masana, E, Martínez-Díaz, J.J., Hernández-Enrile, J.L., Santanach, P. (2004): The Alhama de Murcia fault (SE Spain), a seismogenic fault in diffuse plate boundary. Seismotectonic implications for the Ibero-Magrebian region. J. Geophys. Res. 109, 1-17. doi:10.1029/2002JB002359 
Masana, E., Pallàs, R., Perea, H., Ortuño, M., Martínez-Díaz, J.J., García-Meléndez, E., Santanach, P. (2005): Large Holocene morphogenic earthquakes along the Albox fault, Betic Cordillera, Spain. J. Geodynamics 40, 119-133. doi: 10.1016/j.jog.2005.07.002

Meijninger, B.M.L., Vissers, R.M.L. (2006): Miocene extensional basin development in the Betic Cordillera, SE Spain, revealed through analysis of the Alhama de Murcia and Crevillente Faults. Basin Research 18, 547-571. doi: 10.1111/j. 1365-2117.2006.00308.x.

Mezcua, J., Rueda, J., Blanco, R. M. (2004): Reevaluation of historic earthquakes in Spain, Seismol. Res. Lett. 75, 75-81. doi: 10.1785/ gssrl.75.1.75

Montenat, C., P. Ott d'Estevou (1990): Eastern Betic Neogene basinsA review. In: C. Montenat (ed.), Les Bassins Néogeènes du Domaine Beétique Orientale (Espagne). Documents et Travaux du Institut Géologique Albert-de-Lapparent 12-13, Paris: 9-15.

Montenat, C., Ott d'Estevou, P., Masse, P. (1987): Tectonic-sedimentary characters of the Betic Neogene basins evolving in a crustal transcurrent shear zone (SE Spain). Bulletin Centre de Recherché Exploration Production. Elf-Aquitaine 11, 1-22.

Mora-Gluckstadt, M. (1993): Tectonic and sedimentary analysis of the Huércal Overa region, South East Spain, Betic Cordillera. PhD. Thesis, University of Oxford, Oxford: 300 pp.

Moreno, X. (2011): Neotectonic and Paleoseismic Onshore-Offshore integrated study of the Carboneras Fault (Eastern Betics, SE Iberia). $\mathrm{PhD}$. Thesis, University of Barcelona, Barcelona.

Moreno, X.; Masana, E.; Gracia, E.; Bartolome, R.; Lo Iacono, C.; Rodés, A.; Pallàs, R. (2009): An integrated multiscale paleoseismic and neotectonic approach of the Carboneras Fault Zone, SE Spain, and its marine continuation in the Alborán Sea. American Geophysical Union, Fall Meeting 2009, abstract. San Francisco, California: T21D-1853.

Ortuño, M.C., Masana, E., Buylaert, J. P., Canora, C., Cunha, P., García-Meléndez, E., Martínez-Díaz, J., Murrey, A., Sohbati, R., Štěpančíková, P. (2009): Paleoseismic activity at the southern termination of Alhama de Murcia fault (Southeastern Betics, Spain): geomporphic and trenching evidence along a slow moving fault. American Geophysical Union, Fall Meeting 2009, abstract. San Francisco, California: T21D-1851.

Ott d'Estevou, Ph., Montenat, Ch. (1985): Evolution structurale de la zone betique orientale (Espagne) du Tortonien a I'Holocene. C.R. Acad. Sci. Paris 300, II, 8, 363-368.

Ott d'Estevou, P., Montenat, Ch., Alvado, J.C. (1990): Le Bassin de Vera-Garrucha. In: C. Montenat (ed.), Les Bassins Néogeènes du Domaine Beétique Orientale (Espagne). Documents et Travaux du Institut Géologique Albert-de-Lapparent 12-13, Paris: 165-187.

Pedrera, A., Galindo-Zaldívar, J., Ruiz-Bustos, A., Rodríguez-Fernández, J., Ruíz- Constán, A. (2009a): The role of small-scale fold and fault development in seismogenic zones: example of the Western Huércal-Overa basin (Eastern Betic Cordillera, Spain). J. Quat. Sci. 24, 581-592, doi:10.1002/jqs.1246.

Pedrera, A., Galindo-Zaldívar, J., Ruiz-Constán, A., Duque, C., MarínLechado, C., Serrano, I. (2009b): Recent large fold nucleation in the upper crust: Insight from gravity, magnetic, magnetotelluric and seismicity data (Sierra de Los Filabres-Sierra de Las Estancias, Internal Zones, Betic Cordillera). Tectonophysics 463, 1-4, 145-160. doi:10.1016/j.tecto.2008.09.037

Pedrera, A., Galindo-Zaldívar, J., Sanz de Galdeano, C., López-Garrido, A.C. (2007): Fold and fault interactions during the development of an elongated narrow basin: The Almanzora Neogene-Quaternary Corridor (SE Betic Cordillera, Spain). Tectonics 26, TC6002. doi: 10.1029/2007TC002138.

Pedrera, A., Galindo-Zaldívar, J., Tello, A., Marín-Lechado, C. (2010a): Intramontane basin development related to contractional and extensional structure interaction at the termination of a major sinistral fault: The Huércal-Overa Basin (Eastern Betic Cordillera). Journal of Geodynamics 49, 271-286. doi:10.1016/j. jog.2010.01.008

Pedrera, A., Mancilla, F., Ruiz-Constán, A., Galindo-Zaldívar, J., Morales, J., Arzate, J., Marín-Lechado, C., Ruano, P., Buontempo, L., Anahnah, F., Stich, D. (2010b): Crustal-scale transcurrent fault development in a weak-layered crust from an integrated geophysical research: Carboneras Fault Zone, eastern Betic Cordillera, Spain, Geochem. Geophys. Geosyst. 11, Q12005. doi:10.1029/2010GC003274.

Pedrera, A., Marín-Lechado, C., Galindo-Zaldívar, J., RodríguezFernández, L.R., Ruiz-Constán, A. (2006) Fault and fold interaction during the development of the Neogene-Quaternary Almería-Níjar basin (SE Betic Cordilleras). In: Moratti, G., Chalouan, A. (eds). Tectonics of the Western Mediterranean and North Africa. Geological Society, London, Special Publications, 262, 217-230.

Pedrera, A., Marín-Lechado, C., Stich, D., Ruiz-Constán, A., Galindo-Zaldívar, J., Rey-Moral, C., Mancilla, F. (2012): Nucleation, linkage and active propagation of a segmented Quaternary normaldextral fault: the Loma del Viento fault (Campo de Dalías, Eastern Betic Cordillera, SE Spain). Tectonophysics 522-523, 208-217. doi: oi:10.1016/j.tecto.2011.12.001.

Pedrera, A., Pérez-Peña, J.V., Galindo-Zaldívar, J., Azañón, J.M., Azor, A. $(2009 \mathrm{c})$ : Testing the sensitivity of geomorphic indices in areas of low-rate active folding (eastern Betic Cordillera, Spain). Geomorphology 105, 218-231. doi:10.1016/j.geomorph.2008.09.026

Pedrera, A., Ruiz-Constán, A., Galindo-Zaldívar, J., Chalouan, A., Sanz de Galdeano, C., Marín-Lechado, C., Ruano, P., Benmakhlouf, M., Akil, M., López-Garrido, A.C., Chabli, A., Ahmamou, M., González-Castillo, L. (2011): Is there an active subduction beneath the Gibraltar orogenic arc? Constraints from Pliocene to present-day stress field. Journal of Geodynamics 52, 2, 83-96. doi:10.1016/j.jog.2010.12.003

Poisson, A.M., Morel, J.L., Andrieux, J., Coulon, M., Wernli, R. Guernet, C. (1999): The origin and development of Neogene basins in the SE Betic Cordillera (SE Spain): a case study of the TabernasSorbas and Huércal Overa Basins. J. Petrol. Geol. 22, 97-114.

Reicherter, K., Hübscher, C. (2006): Off-Shore evidence for the 1522 Almería earthquake $(\mathrm{M}>6.5)$ in the Alborán Sea (southern Spain), Journal of Seismology 11, 15-26. doi: 10.1007/s10950-006-9024-0.

Rodríguez-Fernández, J. (1982): El Mioceno del sector central de las Cordilleras Béticas. PhD. Thesis, Universidad de Granada, 224 pp.

Ruano, P., Galindo-Zaldívar, J., Pedrera, A., Marín-Lechado, C. (2007): Paleostresses and recent tectonic activity of the PalomaresCarboneras strike-slip faults (Eastern Betic Cordilleras, SE Spain). Procceding of IUGG 2007, Perugia.

Rutter, E.H., Maddock, R.H., Hall, S.H., White, S.H. (1986): Comparative microstructures of natural and experimentally produced claybearing fault gouges. In: Y. Wang-Chi (ed.), International Structure of Fault Zones, Pure Appl. Geophys. 124, 3-30.

Sanz de Galdeano, C. (1983): Los accidentes y fracturas principales de las Cordilleras Béticas. Estudios Geológicos 39, 157-165.

Sanz de Galdeano, C. (1987): Strike-slip faults in the Southern Border of the Vera Basin (Almería, Betic Cordilleras). Estudios Geológicos $43,435-443$.

Sanz de Galdeano C. (1989): Las fallas de desgarre del borde Sur de la cuenca de Sorbas Tabernas (norte de Sierra Alhamilla, Almería, Cordilleras Béticas). Bol. Geol. y Min. 101, 73-85.

Sanz de Galdeano, C. (1990): Geologic evolution of the Betic Cordilleras in the western Mediterranean, Micoene to present. Tectonophysics 172: 107-119.

Sanz de Galdeano, C., Alfaro, P. (2004): Tectonic significance of the 
present relief of the Betic Cordillera, Geomorphology 63, 3-4, 175190. doi:10.1016/j.geomorph. 2004.04.002.

Sanz de Galdeano, C., Lopez Casado, C. (1988): Fuentes sísmicas en al ámbito Bético-Rifeño. Rev. Geofis. Madrid 44, 175-198.

Sanz de Galdeano, C., López-Casado, C., Delgado, J., Peinado, M.A. (1995): Shallow seismicity and active faults in the Betic Cordillera. A preliminary approach to seismic sources associated with specific faults. Tectonophysics 248, 293-302.

Sanz de Galdeano C., Rodríguez Fernández, J., López Garrido A.C. (1985): A strike-slip fault corridor within the Alpujarra Mountains (Betic Cordilleras, Spain). Geol. Rundsch. 74, 3, 641-655. doi:10.1 $111 / \mathrm{j} .1365-2117.2006 .00284$

Sanz de Galdeano C., Shanov S., Galindo-Zaldívar J., Radulov A., Nikolov G. (2010): A new tectonic discontinuity in the Betic Cordillera deduced from active tectonics and seismicity in the Tabernas Basin. Journal of Geodynamics 50, 57-66. doi:10.1016/j. jog.2010.02.005

Sanz de Galdeano, C., García-Tortosa, F.J., Peláez, J.A., Alfaro, P., Azañón, J.M., Galindo- Zaldívar, J., López Casado, C., López,-Garrido, A.C., Rodríguez-Fernández, J., Ruano, P. (2012): Main active faults in the Granada and Guadix-Baza basins. Journal of Iberian

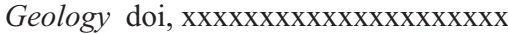

Sanz de Galdeano, C., Vera, J. A. (1992): Stratigraphic record and palaeogeographical context of the Neogene basins in the Betic Cordillera, Spain. Basin Res. 4, 21-36.

Scotney, P., Burgess, R., Rutter, E.H. (2000): 40Ar/39Ar age of the Cabo the Gata volcanic series and displacements on the Carboneras fault zone, SE Spain. J. Geol. Soc. London 157, 1003-1008.

Silva, P.G., Goy, J.L., Somoza, L., Zazo, C., Bardají, T. (1993): Landscape response to strike-slip faulting linked to collisional settings: Quaternary tectonics and basin formation in the Eastern Betics, southeast Spain. Tectonophysics 224, 289-303.

Soler, R., Masana, E., Santanach, P. (2003): Evidencias geomorfológicas y estructurales del levantamiento tectónico reciente en la terminación sudoccidental de la falla de Alhama de Murcia (Cordillera Bética Oriental). Revista de la Sociedad Geológica de España 16, 123-133.

Soto, J.I., Comas, M.C., de la Linde, J. (1996): Espesor de sedimentos en la cuenca de Alborán mediante una conversión sísmica corregida. Geogaceta 20, 382-385.

Soto, J.I., Fernández-Ibáñez, F., Fernàndez, M., García-Casco, A. (2008): Thermal structure of the crust in the Gibraltar Arc: influence on active tectonics in the western Mediterranean. Geochem. Geophys. Geosyst. 9, Q10011. doi:10.1029/2008GC002061.

Stapel, G., Moeys, R., Biermann, C. (1996): Neogene evolution of the
Sorbas basin (SE Spain) determined by paleostress analysis. Tectonophysics 255, 291-305.

Stich, D., Ammon, C.J., Morales, J. (2003): Moment tensor solutions for small and moderate earthquakes in the Ibero-Maghreb region. $J$. Geophys. Res. 108, 2148. doi: 10.1029/2002JB002057

Stich, D., Martín, R. Morales, J. (2010): Moment tensor inversion for Iberia-Maghreb earthquakes 2005-2008. Tectonophysics 483, 3-4, 390-398. doi:10.1016/j.tecto.2009.11.006

Stich, D., Aguacil, G., Morales, J. (2001): The relative locations of multiplets in the vicinity of the western Almería (southern Spain) earthquake series of 1993-1994. Geophys. J. Int. 146, 801- 812.

Stich, D., Serpelloni, E., Mancilla, F., Morales, J. (2006): Kinematics of the Iberia-Maghreb plate contact from seismic moment tensors and GPS observations. Tectonophysics 42, 295-317. doi: 10.1016/j. tecto.2006.08.004.

Stokes, M (2008): Plio-Pleistocene drainage development in an inverted sedimentary basin: Vera basin, Betic Cordillera, SE Spain. Geomorphology 100, 193-211. doi:10.1016/j.geomorph.2007.10.026

Stokes, M., Mather, A.E. (2000): Response of Plio-Pleistocene alluvial systems to tectonically induced base-level changes, Vera Basin, SE Spain. Journal of the Geological Society of London 157, 303-316.

Stokes, M., Mather, A.E. (2003): Tectonic origin and evolution of a transverse drainage: the Río Almanzora, Betic Cordillera, SE Spain. Geomorphology 50, 59-81.

Tahayt, A., Mourabit, T., Rigo, A., Feigl, K.L., Fadil, A., McClusky, S., Reilinger, R., Serroukh, M., Ouazzani-Touhami, A., Ben Sari, D., Vernant, P. (2008): Present-day movements of tectonic blocks in the Betic-Rif Arc from GPS measurements 1999-2005. Comptes Rendus Geoscience 340, 400-413, doi:10.1016/j.crte.2008.02.003.

Van de Poel, H.M. (1991): Messinian stratigraphy of the Nijar Basin (S.E. Spain) and the origin of its gypsum-ghost limestones. Geologie en Mijnbouw 70, 215-234.

Vernant, P., Fadil, A., Mourabit, T., Ouazar, D., Koulali, A., Davila, J.M., Garate, J., McClusky, S., Reilinger, R.E. (2010): Geodetic constraints on active tec- tonics of the Western Mediterranean: implications for the kinematics and dynamics of the Nubia-Eurasia plate boundary zone. J. Geodyn. 49, 123-129, doi:10.1016/j. jog.2009.10.007.

Weijermars, R. (1985): Uplift and subsidence history of the Alborán Basin and a profile of the Alborán Diapir (W-Mediterranean). Geol. Mijnbouw 64, 349-356.

Weijermars, R. (1987): The Palomares brittle ductile shear zone of Southern Spain, Journal Structural Geology 9, 139-157. 